\title{
What a Difference a Sea Makes in the Decameron: The Mediterranean, a Structural Space of THE Novella
}

\section{Roberta Morosini}

\begin{abstract}
This essay presents a reading of the Mediterranean sea as a narrative space in the Decameron. Through a reading of text and images, the paper illustrates the categories of mobile/static and foreign/domestic at work in the Decameron. It also introduces a third epistemological category, hybridity, at the centre of this study, which aims to establish the role and function of the Mediterranean in the fabula - the plot development-as well as in the structure of the novella itself, and ultimately in Boccaccio's poetics.

Is the Mediterranean a "structural space" in (and of) the novella, hence in/of the Decameron? Does it make and forge "experiences" of women of different religions (and social origins) that differ from the experiences of men in the Medieval Mediterranean? The article proposes different cases of women travelling in the Decameron and discusses the paralysis and diaspora of women's identity in the hybrid space of mobile Mediterranean, a foreign space of immobilization and dangers.
\end{abstract}

Fundavi, serenissime rex, quibus potui armamentis hinc inde naviculam, ne estu procellosi maris aut ventorum adverso impetu pelleretur in litus, et illisa ruptis compagibus solveretur. (Genealogie, Proem. XV 1) ${ }^{1}$

\footnotetext{
1 "I have now secured my little bark, O most clement King, by such means as I could, for fear she should be driven ashore by the wash of a stormy sea or the counterforce of the wind, with joints sprung and timbers crushed" (Osgood 102, modified by Lummus 101).
} 


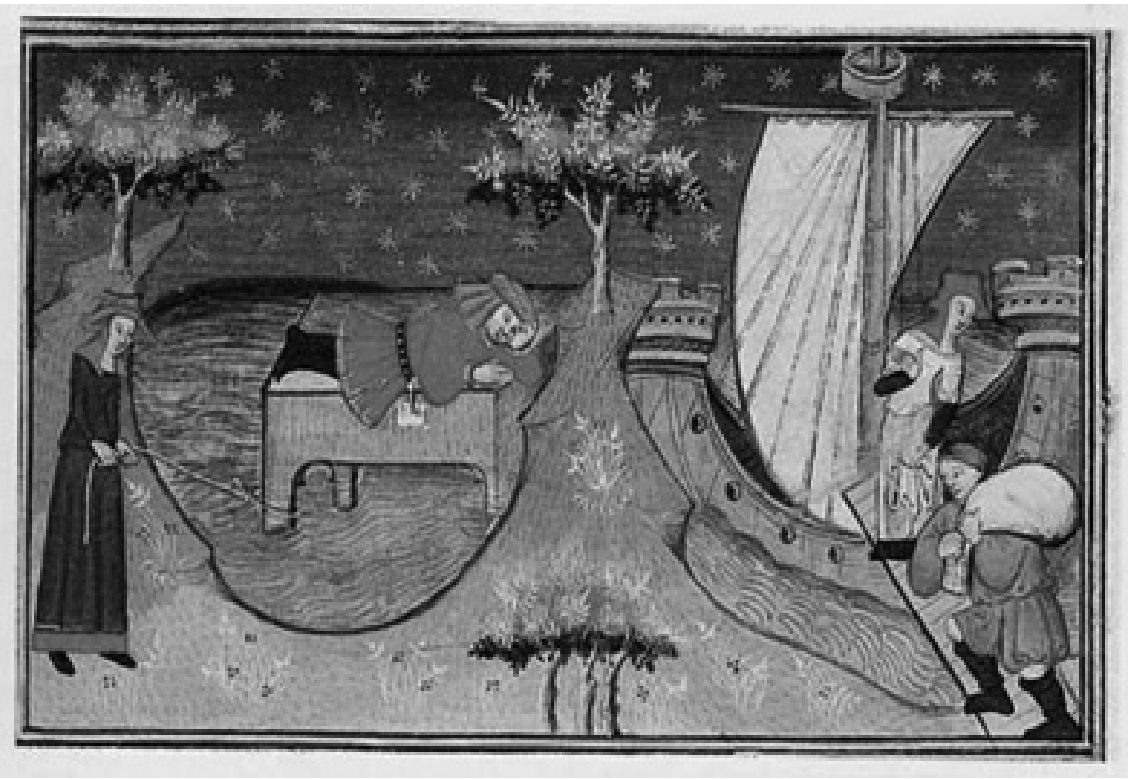

Landolfo Rufolo and... women and the sea, in Boccaccio, Decameron II 4, trans. Laurent de Premierfait, ms. 2561, fol. 57r, 1400-1424 ca., Österreichische Nationalbibliothek, Wien.

This image of Landolfo Rufolo from the Österreichische Nationalbibliothek of Vienna eloquently illustrates the categories of mobile/static and foreign/domestic and leads to the third category of hybridity at the centre of this study, which aims to establish the role and function of the Mediterranean in the fabula - the plot development - as well as in the structure of the novella itself, and ultimately in Boccaccio's poetics. ${ }^{2}$

The sea, which is always the Mediterranean (except for novella II.8), is the protagonist of 10 stories in the Decameron, especially in Days II and V, not to mention all of the instances when it is not explicitly cast as a "space" that is crossed

\footnotetext{
${ }^{2}$ I would like to thank Simone Marchesi for the generous invitation to take part in his conference Categories of the Decameron and Katherine Brown and Luca Somigli for their precious feedback on the first and last redaction of this essay.
} 
by the characters, but still permeates the story deeply, as in VIII.10 and V.7.3 Despite the introduction of the matière de Bretagne in the twelfth century, when writers began to prefer that their protagonists cross the forest, adventures at sea remained a current literary theme in thirteenth- and fourteenth-century love stories; one might think of Aucassin et Nicolette and Floire et Blancheflor, whose plots both unfold within a maritime world of the abduction and forced travel of women in the Mediterranean (the Saracen Nicolette is kidnapped and forced to convert, then kidnapped again by Saracens who bring her back to her native Carthage whence she flees in men's clothes; Blancheflor's Christian mother is abducted in Compostela by the pagan king Felix who waits for his spoils on his boat, and Blancheflor herself is sold to merchants from Alexandria).

This leads to the first question addressed in this paper: In the Decameron, is the sea a "structural element" in/of the novella and of the work as a whole? The second question is strictly related to the first and examines further the function of the sea as a narrative space within Boccaccio's poetics. In fact, as Chantal Connochie-Bourgne argues in her introduction to Mondes marins du Moyen Âge, "telling and retelling the presence of the sea in a fictional universe, manifests the authorial desire to structure the romance or epic space" (my translation, 8). Does the sea in the Decameron constitute a border between ici et ailleurs, from one shore to the other of the Mediterranean, from East to West, and from Islam to Christianity? Is it a privileged literary space of ritual passages for those who cross it, as it is for Tristan? ${ }^{4}$

I intend to show that the sea represents a functional structural space of the novella just as it did in the courtly romance of the twelfth and thirteenth centuries, as Corbellari convincingly showed ("La mer, espace structurant du roman courtois"), but with a difference: the shift from the literary to the realistic role assigned to the sea leads to Boccaccio's invention of the narrative space of modernity as liquid and hybrid, as is the world portrayed in the Decameron is also "liquid" and hybrid.

In the narrative writings of the Middle Ages, the representation of the sea locates itself at the merging of four different traditions that present the liquid

\footnotetext{
${ }^{3}$ I will not address these two stories here, which I study in depth in Il mare salato. A study of "The Tale of Salabaetto and Iancofiore: Decameron VIII.10" in pan-Mediterranean terms is due to appear in the volume on Day Eight in the Lectura Bocaccii series, edited by William Robins and published by University of Toronto Press.

${ }^{4}$ See Pastré.
} 
element within a system of values that changes from one tradition to another (the Celtic, Greek, Roman, and Biblical traditions) and its marine imagination is particularly anchored in the Celtic tradition so that "le roman médiéval a developpé un paradigme incontournable de la relation de l'homme à la mer" (Corbellari, "La mer, espace de fragmentation" 111). The sea is a space of exile (e.g., Eliduc, Tristan) but also of encounter (Tristan), a space of fragmentation, that underlines the difference between two kingdoms or two physical or moral forces (Roman de Silence), or of separation where the sea is an element of freedom for those who cross it (Philippe de Beaumanoir's Jehan et Blonde).

While Boccaccio was familiar with this variety of literary traditions, the sea becomes for the writer the privileged narrative space that best mirrors the instability of the sudden, profound, and continuous changes of his world besieged by the calamity of the plague: liquid, mobile, (suddenly) foreign, hybrid. An example is Pampinea's speech to the rest of the brigata, where the usual pattern of a domestic space, such as the house, has become foreign to her and others (Intro.59-60), and her desire to find joy and be safe now relies on the "outside," outside the city walls of Florence, where they shall see "fresh green hills and plains, fields of corn undulating like the sea" (66). ${ }^{5}$

A study of the sea in the Decameron also proves how it becomes intrinsically functional to the poetics of the work as a political space of Boccaccio's civic humanism. Thus, in this perspective, where political stands for "concerning the polis, hence the city," the Mediterranean turns out to be a spatial extension of the "liquid" city, a space where the narrator Boccaccio continues to underline the inadequacy of behaviours and incongruencies of the city after the devastation of the plague. Boccaccio attempts, through the civil reasoning of the brigata, to launch new secular and urban values for the rebuilding of a new urbanitas at the time of "liquidity" (Morosini, "From the Garden to the Liquid City" 7 and 31).

As for the sea, I argue that when one tries to read it in Corbellari's terms ("La mer, espace structurant du roman courtois" 111-112) as a space of fragmentation, conjunction, separation, and neutralization, its inner features of a liquid spacemobility, foreignness, and hybridity—escape any attempt at categorization, just like the world at play in the Decameron.

\footnotetext{
${ }^{5}$ All English citations of the Decameron are from Giovanni Boccaccio, The Decameron, ed. and trans. G. H. McWilliam. The Italian text is from Giovanni Boccaccio, Decameron, ed. Amedeo Quondam, Maurizio Fiorilla, and Giancarlo Alfano.
} 
In this paper, I will discuss two aspects concerning the role of the sea in the Decameron: the formation of characters who cross it and the diegesis of the novella itself, which are interconnected. The study of the impact that the Mediterranean sea has on men and women travellers and the way these travellers affect the lives and the community in the lands they reach show the Mediterranean as a hybrid space that is functional to the lives of the men who cross it, but not of the women. It turns out, moreover, to be an essential structural element of the novella: the Mediterranean and the novella genre share the three categories of mobile, foreign, and hybrid.

\section{Mobile-static: the hybridity of the Mediterranean and the novella}

In the image I chose from the Vienna manuscript, Landolfo is represented in his mobility, as in the story: he sails from Ravello on the Amalfi Coast to Cyprus, through the Aegean sea, and then to Cephalonia; he is shipwrecked on Corfu, leaves for Apulia, to the cities of Brindisi and Trani, and then returns to Ravello. In the right-hand corner of the image, he is in the sea that is the co-protagonist of the story (II.4), and in the second sequence, he is getting on the boat, where Fortuna herself welcomes him, ready to sail (Fortune is the theme of Day II). While he is represented with a certain dynamism, the woman is on land. Where is the hybrid and what do I mean by using this category here?

I recently proposed a mapping of the Mediterranean by using Homi K. Bhabha's notion of "in-between" and Henri Lefebvre's notion of "representational spaces" to advocate for a new location of Mediterranean culture in the "in-between space," a hybrid location. To use a word that works more effectively in Italian, or in French, "Mediterraneity" in itself does not exist and manifests itself as "encounter": plurality and heterogeneity on the one side; exchange and

\footnotetext{
${ }^{6}$ See Epstein's 2014 study, "Hybridity."

${ }^{7}$ Lefebvre notes that while representations of space "instantiate the dominant space in any society," representational spaces are presented "directly through the associated images and symbols, of 'inhabitants' and 'users'." I refer here to the English translation of Lefebvre, The Production of Space (39). See also Morosini, "The 'In-between Representational Spaces', forthcoming.

${ }^{8}$ Guarracino examines the word Mediterraneità. See also the study of Ruel.
} 
connection on the other. ${ }^{9}$ Different elements, coming from different traditions, "meet" in the interstices, thereby producing a hybrid space of plurality and what Peregrine Horden and Nicholas Purcell call "connectivity."

The notion of hybridity defines the sea as the space that is best suited to organize the conflicting structure of the novella genre, since "the critical power of hybridity is in its ability to question what appears natural and complete, to problematize naturalized boundaries" (Kuortti and Nyman 1). In the Decameron, maritime space is rarely the equivalent of the Western forest or the Oriental desert, as Jacques Le Goff justly claims for most medieval texts that feature the sea (40-41). This uniqueness of the function of the Mediterranean as a hybrid space in the Decameron is served by the novella, a genre that eludes a linear codification in respect to other literary genres (fable, parable, exemplum) and whose main structural features were identified by Michelangelo Picone: brevitas, the linearity of the story, delectatio, and veritas (Il racconto 50-52). ${ }^{10}$

As Picone showed in several of his studies, the novella, within the narratio brevis, distinguishes itself because it problematizes the world. Hans-Jörg Neuschäfer, who at the Montreal conference in 1982 continued Picone's efforts to provide a canon for the novella genre in the context of other medieval narrative forms (109), identified a number of peculiar features unique to the novella that are useful to this study of the Mediterranean as the privileged structural space of narration. The novella and the Mediterranean are both mobile, heterogeneous, intrinsically ambivalent and conflictual, and both voice the particular (not the general) so that both become, in Boccaccio's poetics, the privileged form (the novella) and space (the Mediterranean) to convey all the shifts and transitions registered in the stories' plots, namely the hybridity of the world narrated in his Decameron.

The importance given in this genre to the particular rather than the general is fundamental for the description of the hybridity of the Mediterranean in the Decameron, which reflects the hybrid nature of the novella itself. I believe that Neuschäfer's emphasis on the relativization of the norms and the casuistry

\footnotetext{
9 See my introduction to Boccaccio veneto 9-11 and Morosini, "Connettività e "Convivencia" 13-18; see also the introduction to Morosini, Boccaccio geografo; the indispensable Matvejević, Breviario mediterraneo; and, by the same author, "Pane zingaro" 21-24.

${ }^{10}$ See Picone, Di Stefano, and Stewart; and more recently Marchesi; Picone, Boccaccio e la codificazione della novella; and the post-mortem volume by Picone (1949-2009), Il racconto nel Medioevo.
} 
of values as main features of the novella can also be applied easily to a study of the role of the Mediterranean in the Decameron. I will illustrate these points in some tales of the Decameron: II.4; II.6; II.7; II.9; IV.3; IV.4; V.1; V.2; and in the miniatures that illustrate them in the Vienna manuscript 2561 and in Paris, BnF, mss. Fr. 239-240 and It. 63. ${ }^{11}$

\section{Foreignness: inside-outside}

Who travels? Mainly men; in the rich book of medieval travel literature, women are missing. In Terre ignote, strana gente, which relates tales of medieval travellers, Duccio Balestracci devotes only a short paragraph to "viaggiatrici fantasma" (ghost women travellers), explaining that, in his repertory, "an entry" — and I would say, playing with the Italian word for entry, voce, a voice-is missing: "that of women travelers" (21). Women do not travel for business, military, or diplomatic reasons or for pleasure, discovery, or exploration. Women might travel as pilgrims, like the noble lady of Gascony (I.9), who goes from Cyprus to the Holy Sepulchre, but "on her return journey, she was brutally assaulted by a pack of ruffians" (291; fig. 1). In the illumination of $\mathrm{BnF}$ manuscript Italien 63 (fol. 29v), the artist chose to represent her not outside where she has been raped, but inside while, on her knees, she is trying to wake the king of Cyprus from his moral slumber to do justice for her; when Rinaldo is attacked by the brigands, justice is instead quickly carried out (fig. 2).

How dangerous was the outside world? The threatening dark boats against a wild background in Gentile da Fabriano's Nativity convey the everyday dangers outside the city walls (figs. 3-4). At least in literature, the dimension of travelling was unknown to the female world, possibly because travel is related to action, movement, the external world, and the public; ${ }^{12}$ women are associated with permanence and rarely travel to discover or explore. In the third story of Day V, the victim of the dangers of the "outside" is Agnolella. Fleeing from the brigands who attacked her and her boyfriend, she admits that she prefers "to be torn apart by men rather than eaten alive by the animals in the woods" (748).

\footnotetext{
${ }^{11}$ See also Branca, in particular vol. II.

12 On the political and social implications of these categories (inside-outside and privatepublic), see Morosini, “'E lavorando semini ciascuno’.”
} 
Mobility is only an illusion for some women travellers, since they never cross the "outside" - from the city walls, the land, and the sea — by choice: they are forced to cross the sea because they are abducted by a potential lover, as is the case with Iphigenia (V.1); by potential rapists, as in Restituta's case (V.6); because their father gave them in marriage to another king, as is the case of the Muslim Alatiel (II.7) and of the princess of Tunis (IV.4); or because they are kidnapped by a pirate (II.10). The young Muslim Alibech from the Tunisian city of Gafsa seems to have chosen to be a pilgrim to learn how "to serve God," and Beritola, to have initiated a journey out of Sicily; however, the first starts travelling more on a whim than for a real desire to convert to Christianity (III.10.6), whereas the second starts only through fear, with an absolute lack of awareness of the sea and its dangers (II.6). The unusual case of a woman traveller from France to Florence in III.9 proves that travelling by land and with company (a cousin of hers and a maidservant), with a good quantity of money and precious jewels, all in pilgrim's garb, can guarantee a safe journey "outside," even for a woman.

Could the sea be a negotiable external and foreign space where women can travel, be more aware of their identity, be changed by their experience, and encounter the other?

\section{Static women and mobile men crossing the Mediterranean Sea}

To go back to the image I used to open this study, Landolfo Rufolo with his sack on his shoulder is ready to board ship and sail to Apulia and then back home to Ravello. He is a richer and better person: the experience in and of the Mediterranean really has forged his life. The woman who saves him from the shipwreck is instead on land; she recalls the legendary Roman matron Claudia Quinta who, according to legend, used ropes tied to her sash to single-handedly free a ship that, carrying a statue of Cybele (around 205 BC) and travelling from Anatolia to Rome (Palatine Hill), had run onto a sandbank at the mouth of the Tiber (fig. 5).

The image of Claudia Quinta reinforces the static relationship of women with water and navigation: the inside and fixity correspond to Penelope and the functions required of a woman. Ulysses may enjoy the outside, openness, mobility, and contact with the other, ${ }^{13}$ but Penelope stays at home. Also, the relationship of women with navigation is static; women's location is the "stantiality" and

${ }^{13}$ I talk more about Penelepe (static) and Ulysses (mobile) in Morosini, "Penelopi in viaggio." 
immobility of the land. Most of the illuminations featuring women and boats represent a static boat in a static sea; sometimes the boat seems eloquently to be one with the land, like the one carrying Medusa (fig. 6), who has not chosen to travel, just as Helen of Troy who, in the British Library manuscript, experiences the Mediterranean as a space that is "not social" (in terms of Zumthor's "social space" $)^{14}$ and that qualifies itself mainly as masculine-of men or soldiers that claim their booty (fig. 7). I find that the best visual example of the immobile travelling of women is the abduction of Helen of Troy painted by Xanto Francesco Avelli, as it reveals the drama of women and the sea: through her arm, Helen creates continuity between land and sea (fig. 8). She turns toward her home, her land: she is not ready to embark on a journey she has not chosen.

While the image of Landolfo Rufolo and Claudia Quinta point to the nature of the relation between women and the sea, the image of Helen of Troy exemplifies the modality and the paradox of women's travels in the Mediterranean: they are statically mobile since they must be taken by others into a foreign space in a condition of "apparent movement" while they remain encased in their domestic space; ${ }^{15}$ the body is moving but Helen's attention belongs to the land. They cross and encounter the foreign, but they do not actively move; they are paralyzed in a male world that is in constant turmoil, as if they were blocked in their domesticity, failing to experience the foreign, to learn about it and about themselves.

In the tales of Beritola and Alatiel (II.6 and 7), their journeys seem to be a synecdoche of their existence, closer to the permanence of Penelope than the mobility of Ulysses. Branca compares the adventure of Alatiel in the Mediterranean to that of Ulysses. I would add that the ironic connection between Dante's Ulysses (Inf. XXVI) and Alatiel is made when Costanzio takes away the beautiful Muslim from the duke of Athens and orders that "de' remi dessero in acqua e andasser via. Li quali, non vocando ma volando, quasi in sul dí del seguente giorno a Egina pervennero" (II.7.74; emphasis added). However, the ideal couple represented by Ulysses-Penelope is re-semanticized by masculine values, though differently from Ulysses who, in his account, specifies his responsibility for the shipwreck by means of the "we" when he says that "dei remi facemmo ali al folle volo" (Inf. XXVI.125). As Dante's Ulysses narrates how they put wings to their "folle volo" and have no

\footnotetext{
${ }^{14}$ While I owe the notion of "space-movement" to Braudel, I extend Zumthor's idea of what a "social space" is in the Middle Ages (Zumthor, La misura del mondo 40) to the sea as a space that tends to become the signifier of a social significant modality.

${ }^{15}$ See Morosini, "Penelopi in viaggio."
} 
desire to go home, Homer's Odysseus goes through a number of obstacles that change him, but his only desire is to go home. While Alatiel is not the agent of the "folle volo," she goes through a lot as well during her journeys, yet she also wishes to return home and she does. Once she is back in Babylon, she is exactly as she was when she left; in fact, she is put out to sea again to marry the king of Algarve as if nothing happened. When Beritola is shipwrecked on the island of Ponza, the pirates take away her sons, and she becomes animal-like: hairy and nourishing two goats. These women travel without changing, while the world around them moves hectically. ${ }^{16}$ If there is a change, it is only physical: Alatiel loses her innocence and Beritola turns into an animal. Both of their losses are superficial and show their dehumanization, even if this means more specifically for Alatiel a loss of identity ${ }^{17}$ rather than their education and development or enrichment. As Le Goff (116-117) writes, "what is wild [silvatico] is not what is beyond the human reach, but what remains at the margins of human activities" (author's emphasis; translation mine).

Both stories bring out the dramatic element in the hybrid nature of the Mediterranean when women cross it, because in most cases narrated in the Decameron, women do not choose to travel. Also, through inverse processes, both women are returned once again to their pristine status at the end of the narrative.

In "Penelopi in viaggio," I look at some novelle in the Decameron and argue that when women cross the waters, they freeze; sea-movement becomes sea-static. Here, I want to expand my comments on women's journeys in the Decameron to focus on experiences and dangers, such as rape, in both domestic and foreign spaces. Women's identities undergo both paralysis and dispersion in the hybrid space of the Mediterranean. Often this sea is seen as a space of mercatura, of exchange, ${ }^{18}$

\footnotetext{
${ }^{16}$ Beritola's story unfolds within the events that go from the death of Manfred in the Battle of Benevento (1266), and the arrival of the Angevins in Sicily, to their departure at the following Vespers (1282) and the arrival of the Aragonese that brings the family together.

${ }^{17}$ Alatiel has not chosen but, rather, is forced to have a sexual encounter.

${ }^{18}$ Also Ferrante tends to approach the sea in the Decameron and in particular in II.10 as the eloquent space of "the vast trading world of the Mediterranean" (Politics, Finance, Feminism, 163), while more recently Kinoshita and Jacobs argue that the Mediterranean in the Decameron and in particular in II.7 is a space of "hermeneutic indeterminacy [...]. It conjures the Mediterranean as a place of both confessional and interconfessional violence - each regulated more by the law of desire than the rule of ideology or principle and of practical expediency, where Christian merchants routinely skirted prohibitions on Muslim trade in part by declining
} 
and to borrow Zumthor's notion, it is seen as a "social space," a space that can be personal, individual, and heterogeneous but still intimate. It is hard to see the destiny of travellers like Alatiel (II.7) and Landolfo Rufolo (II.4) as forged by the sea, a force that "regulates life, embraces it, determines it, fascinates it." ${ }^{19}$ This forging of the traveller's identity happens, and is very true, for Landolfo Rufolo as well as for other male travellers like Martuccio Gomito (V.2) and Salabaetto (VIII.10), ${ }^{20}$ but the same movement definitely does not shape or determine the lives of the women who cross that sea. Instead, it affects the structure of the novella.

The women travelling the Mediterranean in the Decameron, like Biancifiore, who journeys from Marmorina (Verona) to Alexandria in Egypt in the Filocolo, and her Old French spiritual sister Blancheflor ${ }^{21}$ are all mercantile commodities, objects of exchange in a world of merchants who easily pass for pirates in the Decameron, like the young Sicilian men who stop on their way home from Naples on the shores of Ischia to freshen up and, as soon as they see Restituta, kidnap her (V.6). ${ }^{22}$ See how the artist of French manuscript 239 also depicts the kidnapping of Restituta (fig. 9): the boat is not moving but already set up to receive the spoils, namely the woman who is being taken by the same gesture of possession that coincides with the arms of the kidnappers around her waist, emphasizing her forced appropriation as mere prey.

New Penelopes, the women travellers in and of the Mediterranean, face the sea in a journey they have not chosen with the silence of the Greek heroine, paralyzed and immune to changes and to the world that surrounds them. The sea is strictly structural to Beritola's experience and to the plot of the novella but is not an agent of change for the traveller, as is brilliantly shown by the artist of manuscript It. 63 (fig. 10): he focuses on Beritola's exile and near-dehumanization, in

to specify their ships' destinations. Most of all, the tale of Alatiel conjures the Mediterranean as a space of circulation and exchange" (186).

${ }^{19}$ See Zumthor, La misura del mondo 33.

${ }^{20}$ See Morosini, “The Merchant and the Siren. Commercial networks and 'Connectivity' in Mediterranean 'space-movement', from Jacopo da Cessole's De ludo scachorum to Decameron VIII 10," in Studi sul Boccaccio 46 (2018): 99-135.

${ }^{21}$ I talk about Biancifiore and Blancheflor travelling as objects in the Mediterranean in Morosini, "Per difetto rintegrare» and in particular in Racconti e immagini del mare salato (forthcoming).

22 The merchant Landolfo Rufolo (II.4) and Martuccio Gomito (V.2) both decide to become corsairs to get rich, and even Gerbino (IV.4) shares more with merchants (and pirates) than with his royal family. More on Restituta can be found in Morosini, "Restituite dal mare." 
an attempt to convey the dramatic binary opposition occurring in the story-that of the present and mobile sea and the remote and immobile cave. On one side lie the sea and its waters that bring Corrado II Malaspina and his wife, who are portrayed as two citizens who return home to Lunigiana from a pilgrimage in Apulia (II.6.18); and on the other lies the cave where Beritola fully belongs and where, in fact, she is already represented as an animal. In a political reading of the story and the role of the sea, Corrado emerges as the liberal political figure portrayed by Dante (Purg. VIII.118-120), his travel in the company of his wife appearing as a form of his open engagement in the community. This is also evidenced by his attempt to reintegrate Beritola into civic life, making sense of the opposition between their movement/mobility and her immobility/isolation.

Remote from the rest of the world, on the island of Ponza where she has been taken by chance and casual winds, Beritola goes through a dehumanization that finds its new space in a cave, the emblematic space of her exclusion from the world..$^{23}$ The artist of the French manuscript Arsenal 5070 (fig. 11; France, fifteenth century, $2^{\text {nd }}$ quarter ${ }^{24}$ prefers to ignore the cave and Beritola's animallike transformation, choosing to capture her lack of awareness of the sea, and therefore of her place in the world and her civic responsibility, in one precise shot: she is not an animal but a woman seated on a bare rock, all nestled in herself, not watching the pirate's ship taking away her sons along with her maid. Right in the opposite direction, there is a city with its towers and fortifications and the sea that meaningfully and dramatically marks her separation from the city that the brigata is trying to build by means of new lay and urban values through their storytelling. ${ }^{25}$ In the middle of the scene, between Beritola and the city, are two boats: one brings Corrado and his wife to Ponza and the other shows the boat facing in the direction of the city where the nurse fits in more than Beritola, a failing mother, does. ${ }^{26}$ Beritola's relation with the sea is one of exclusion and she is

\footnotetext{
${ }^{23}$ For more on the debate on culture and nature in Decameron II.6, see Bolduc; and Morosini, "Fu in Lunigiana'."

${ }^{24}$ The same miniature is in the Vatican manuscript Pal. Lat. 1989.

${ }^{25}$ See Morosini, "From the Garden to the Liquid City."

26 The "wise nurse" is portrayed as a mother on the boat of the pirates (see II.6.29, where she is described as wise and thoughtful despite her poor origin) and is sold with the two boys to Guasparrin Doria. She changes the name of the older boy from Giuffredi to Giannotto of Procida, and she claims to be their mother in order to protect them from the Genoese who
} 
the real outcast in the story, not her second born whom she named "Lo Scacciato" (The Outcast), for she is crossing the sea in Lipari. Born during a journey at sea, Lo Scacciato is the child of the new mobile and hybrid society and he, in contrast to his older brother, adapts easily to the mobility of the new society; furthermore, he ends up marrying the daughter of his master Guasparrin, when the shrewd merchant learns about the family origins of the boy and the financial advantages of this union. Beritola's oldest son, Giannotto, is still absorbed in the old world where nobility of blood determines the inactivity of the character, which stands out even more dramatically in the mobility of the Mediterranean. His failure to adapt to the new world is conveyed through his failed maritime experience. The sea turned him from a nobleman into a slave and then a servant: Giannotto is first kidnapped by pirates who take him to Genoa, where the booty from their acts of piracy is divided among the owners of the boat (II.6.27) — merchants who invested in equipping the boats for corsair activities—and he ends up in the hands of Guasparrino of Doria. After eight years, he refuses to continue to be a servant ("sdegnando la viltà della servile condizione," II.6.22), and at the age of 16, he chooses to set sail, boarding one of the boats going to Alexandria in Egypt. He admits that he has been "roaming" ("tapinando per lo mondo," II.6.42) for a total of 14 years, four of which were spent crossing the sea in many places in and of the Mediterranean ("salito sopra galee che in Alessandria andavano, dal servigio di messer Guasparrino si partì e in più parti andò in niente potendosi avanzare," II.6.33; emphasis added). His voyages were undertaken not in order to change his current social position, but rather to regain his noble condition; this desire motivates all his actions and also underlies his anxiety to be recognized as a nobleman. ${ }^{27}$ His aimless roaming proves the hybridity borne out of the social changes and shows the displacement of a social class that is dysfunctional in the liquid city. Giannotto is unaware of the new situation and unable to adapt and work to change his life, hence crossing the sea is a failure for him, differently from Zinevra (II.9), who happens to leave from the same city of Genoa for the same destination but with more effective results, as she is skilled like a man, namely, as a merchant.

\footnotetext{
were clearly on the side of the Angevins, though the children were the sons of Arrighetto at the service of the Swabian Manfred, who was defeated in 1266 by Charles of Anjou.

27 When he is in Malaspina's prison, Giannotto reveals to the guard that his real name is Giusfredi and enjoys boasting about his noble origins, that he is the son of Arrighetto Capece, and that he could regain his nobility if he returned to Sicily (see 118 and II.6.43-46).
} 
In the story following that of Beritola, Decameron II.7, the Saracen Alatiel is sent by her father, the Sultan of Babylon, "by way of special favour" (126) from Alexandria in Egypt to marry the king of Algarve in Northern Morocco. She experiences the entire Mediterranean (Alexandria of Egypt, Sardinia, Mallorca, the Peloponnese, Glarentza, Athens, Aegina, Chios, Smyrna, Rhodes, Cyprus [Paphos], and back to Alexandria) as a foreign space. She survives thanks to an awareness of her "alterity" because of her different faith. As in Beritola's case, the ship is taken in a different direction from the one she intended, and as in that story, the sea does not modify the heroine's character-not to the extent that it modifies Landolfo Rufolo's. Alatiel is viewed simply as goods in a world of merchants, "quasi amore così questo dovesse patire come la mercatantia o i guadagni fanno" (II.7.40). Love is a trade and women are merchandise offered at a high price and whose profits can be honestly shared:

I due giovani genovesi essendosi l'un dell'altro di questo amore avveduto, di ciò ebber insieme segreto ragionamento e convennersi di fare l'acquisto di questo amor commune, quasi amore cosi questo dovesse patire come la mercatantia o i guadagni fanno. (II.7.39; emphasis added)

The hybridity of the medieval Mediterranean as a site of cultural conflicts emerges in this story and leads to questions of faith and identity. Alatiel is able to maintain an awareness of her own identity in a new Christian (foreign) space. In fact, when she realizes that she is among Christians, she chooses to become silent so as not to make herself known by her language as an Arab and asks the other three women who are with her to do the same. ${ }^{28}$

The sea defines itself as a world of men, one that Alatiel experiences merely as the men's spoils or trophy, although some critics keep focusing on the pleasure she takes from her sexual encounters. The illumination from the manuscript It. 63 (fig. 12) powerfully captures the drama of Alatiel, who cannot even be seen

\footnotetext{
${ }^{28}$ It is worth recalling that when Pericone saw the boat, he sent one of his servants to clamber aboard. At this point, we are not yet informed of Alatiel's reaction, as she is "just" one of the women who survived the shipwreck; nevertheless, Panfilo anticipates the problem of language and identity that is central to the story: "Le quali [donne], come costui videro, piangendo più volte misericordia adomandarono, ma accorgendosi che intese non erano né esse lui intendevano con atti s'ingegnarono di dimostrare la loro disaventura" (II.7.19).
} 
among all those oars in a scene recalling war and blood. It is the same world and the same experience that Iphigenia has of the liquid element (V.1). This story, like V.7, unfolds in the Eastern Mediterranean of the Aegean Sea that Steven A. Epstein describes as

an amazingly complex contested region. Greek states, French principalities, Turkish emirates, Venetian and Genoese colonies, the Hospitalers on Rhodes, Catalan adventurers, Serbian and Bulgarian kingdoms, and others established mixed relationships and fought among themselves to control the shores of the Aegean. No other region of Europe or the Mediterranean became a cynosure of so many ethnicities in such a small place. ${ }^{29}$

Iphigenia is forced to go from Cyprus over the Aegean Sea to Rhodes, Crete, and Cyprus again. Yet like Alatiel, she, too, is mere prey, forced to travel when Cymon kidnaps her to prevent her from marrying Pasimunda in Rhodes. After various bloody episodes, Cymon and Iphigenia return to Cyprus, while Lysimachus (who had helped Cymon escape from prison in Rhodes) and Cassandrea go to Rhodes; nonetheless, if the end of the story allows Iphigenia to return home, she still remains "una preda" throughout, plunder in a battle. ${ }^{30}$

Cymon's transformation through love, from rough and rustic to citizen in Decameron V.1, has shifted the interest of scholarship to the moment of revelation when he sees Iphigenia, as seen in manuscript It. 63 (fig. 13). His transformation echoes of Ameto's vicissitudes in Boccaccio's Comedia delle ninfe fiorentine, rather than Iphigenia's kidnapping at sea. Still, Cymon's becoming a citizen and Iphigenia's kidnapping while forced to sail to be married to Pasimunda both profoundly shape the maritime dimension of the story as in manuscript Fr. 240, where the threatening boat in the background anticipates her destiny as a plunder in a naval battle.

\footnotetext{
${ }^{29}$ This is particularly true of Decameron V.6 and V.7. Epstein, Purity Lost 110.

${ }^{30}$ In an eloquent speech to the young Rhodians who are carrying Iphigenia on their boat to her promised husband, Cymon explains, "Giovani uomini, né vaghezza di preda né odio che io abbia contra di voi mi fece partir di Cipri a dovervi in mezzo mare con armata mano assalire. Quel che mi mosse è a me grandissima cosa a avere acquistata e a voi è assai leggiera a concederlami con pace: e ciò è Efigenia, da me sopra ogni altra cosa amata" (V.1.30-31; emphasis added).
} 
In manuscript It. 63, she is shown lying down on land, peacefully unaware of any dangers, under the gaze of Cymon who limits himself to "looking" at her. Yet the outcome of Cymon's final acquisition of his new status as a citizen does not unfold on land, but only at sea, where contradictions related to the differences that being a citizen makes emerge more powerfully, confirming the Mediterranean as the privileged narrative space of Boccaccio's poetic and civic humanism.

While Cymon as a rustic and illiterate shepherd is innocuous, as soon as he grows wise and gains some awareness as a citizen ("cittadinesco piacere," V.1.8), he decides to abduct Iphigenia at sea from the boat that is taking her to her future husband in Rhodes: since "la quale non potendo io avere dal padre di lei come amico e con pace, da voi come nemico e con l'armi m'ha costretto amore a acquistarla” (V.1.31). The sea shapes itself right away in Cymon's imagination, not as a space of discovery, as one would expect for a man who has always (and only) experienced the bucolic life of the forest, but as a space of conquest by means of weapons and violence, to possess a thing that is strongly desired. There is no industrious way to achieve the object of desire, Iphigenia, as is the case in Day III. His experience of the sea is corrupted from the beginning since he quickly learns that sea and land are spaces of conquest and, as soon as he has become "a citizen" and civilized, he distinguishes himself "nelle cose belliche" (among other things), that is, in the military field: "così marine, come di terra, espertissimo e feroce divenne" (V.1.19). ${ }^{31}$

Nautical images float in this essentially maritime story where naval battles are aimed solely at the gain of spoils (Iphigenia), while boats have the function of receiving the spoils of war, on land or at sea. ${ }^{32}$

\footnotetext{
${ }^{31}$ Lysimachus, whom we remember to be a chief magistrate, speaks to Cymon as a warrior, planning to abduct both women and carry them off to a ship that he had secretly equipped for the "military mission": "Oggi al terzo dì le novelle spose entreranno primieramente nelle case de' lor mariti, nelle quali tu co' tuoi compagni armato e con alquanti miei, ne' quali io mi fiso assai, in sul far della sera entreremo, e quelle del mezzo de' conviti rapite a una nave, la quale io ho fatto segretamente apprestare, ne meneremo, uccidendo chiunque ciò contrastar presumesse" (V.1.61-62). Also, when Cymon and Lysimachus go to the house of the two brothers where the two brides were already seated and about to eat and celebrate with other ladies, they are both concealing weapons under their robes to carry the women off at once to the waiting ship (377). Lysimachus first delivers a speech to fire up his men, and then he divides them into three groups (one dispatched to the harbour so that no one can prevent the men from embarking when the time comes; the other two parties, to Pasimunda's house).

32 When Iphigenia and Cassandrea are abducted on their wedding day, a boat has already been prepared to receive the booty and Cimone and Lysimachus "senza alcuno impedimento stretti
} 
The first time Cymon decides to take Iphigenia, he makes secret arrangements to fit out a ship with everything needed for a naval battle and then sets out to sea. Preparing for battle, he and his men wait on the high seas for the boat taking Iphigenia to Rhodes to her future husband, Pasimunda (just as the Sicilian waited to assault the Saracen boats to take with them the Tunisian princess who was forced by her father to sail to her promised husband [IV.4.15]). At this moment, Cymon speaks vigorously to his crew as a captain preparing for a battle and fights like a raging lion: "fiero come un leone [...], sopra la nave de' rodiani saltò, quasi tutti per niente gli avesse; e spronandolo amore, con maravigliosa forza fra' nemici con un coltello in man si mise e or questo e or quello ferendo quasi pecore gli abbattea" (V.1.28-29).

We are not informed of the impact of the sea on Cymon, and we remain ignorant of the experience that the crossing of its waters has on Alatiel or on other women who are forced to be travellers in the Mediterranean. What is Iphigenia's experience of the sea? Except for when she is at home, in Cyprus, on dry land, we never hear Iphigenia speak; while she is on the high seas, however, we are informed that "she was shedding copious tears and trembled with fear at every buffeting of the waves" (373) and blames the storm on Cymon for his presumption to possess her against her will. Differently from Alatiel, as the artist of the French manuscript 239 shows (fig. 14), she experiences the sea as violently as she does her abduction, since every wave for her is a physical torment: "forte piangendo e ogni percossa dell'onda temendo" (V.1.39). Later, once the storm pushes the ship to Rhodes, we learn that Iphigenia suffered from her abduction as she did from the turbato mare. ${ }^{33}$

The sea definitely does not change Iphigenia, but, rather, it superficially shapes her experience as a woman by becoming the physical space of the abuses perpetrated against her, first by her father and out of economical interests. She is hurt by the sea, and the abuses are out of her control: she is the booty in a naval battle conducted by a man who has finally learned how to be civilized and later is encouraged to fight to gain back his lost prey and the prize by Lysimachus, who happens to be none other than a judge. The space of the sea becomes structural to the story and its maritime dimension to the point of being mentioned in the rubric: "Cimone amando divien savio e Efigenia sua donna rapisce in mare."

\footnotetext{
insieme con la loro rapina alla nave pervennero" (V.1.69; emphasis added).

33 "Efigenia da molte nobili donne di Rodi fu ricevuta e riconfortata sì del dolore avuto della presura e sì della fatica sostenuta del turbato mare" (V.1.47; emphasis added).
} 
Considering the narratological importance of the rubric, what should we make of the equation of Cymon's acquisition of wisdom through love with his decision to kidnap Iphigenia at sea?

The reiteration of the verb "kidnap" and its semantically related words reappear, in conjunction with "prey," in terminology related to a naval battle throughout the story, always in relation to Iphigenia (or Cassandrea). ${ }^{34}$ This repetition leads us to consider Boccaccio's epigraphic irony in the rubric, as he displays, through the narrative space of the sea, the excess and consequences of Cymon's love - that is, not exactly the way a wise and civilized man should love. Boccaccio needs a narrative space in which to display these contradictions and finds it, again, in the sea; he has chosen the foreignness and mobility of the sea to convey the hybridity of a moment of social change parallel to the one occurring in the fourteenth century.

Moreover, from the rubric to the conclusion of the story, the sea proves again to be the extended narrative space of the city evolving around keywords of displacement and identity such as casa/home and terra/homeland and even exile, as the couples leaving from Rhodes take shelter for a few years in Crete. The word casa, understood from our perspective as the house of the two men, Cymon and Lysimachus, ${ }^{35}$ and therefore not "home," appears in the rubric and in the conclusion, ironically, with the word terra that ends the story eloquently: "Ciascun lietamente con la sua visse lungamente contento nella sua terra" (V.1.70). The English translator fails to render the word casa as "house" in the rubric, instead translating it as "home" and thereby implying a chosen intimacy on the woman's part, and, more importantly, the translator replaces the word "prey," implied in "con la sua" (\$70), ${ }^{36}$ with "lady" (378): "And each lived happily ever after with his lady in the land of his birth" (378; emphasis added). Earlier, the narrator specified

\footnotetext{
${ }^{34}$ See presura (capture, abduction; $\$ 47$ ), rapina (spoil[s]; $\$ \$ 52-53,61,69$ ), and preda (prey; "Cimone adunque, più che altro uomo contento dell'acquisto di così cara preda," $\$ 35$ [emphasis added]) become "la guadagnata preda" (the spoils of victory) in the words of Lysimachus (\$\$57 and 58; see also \$59) who, in a vigorous speech, encourages Cymon to regain his prey as he will get his own, that is, Cassandrea. We are not told of Cassandrea's maritime experience, since she is abducted in Rhodes by Lysimachus the same day Iphigenia is taken away by Cymon, on both women's wedding day, and brought directly on a boat that was ready to receive the spoils. 35 “[...] e quindi, divenute lor mogli, con esse a casa loro son richiamati” (emphasis added).

${ }^{36}$ Both women were previously "la loro rapina" (V.1.69; "their spoils," 378) that Cymon and Lysimachus enjoyed ("lieti della loro rapina goderono," \$70).
} 
that Iphigenia and Cassandrea are rapine, and that Cymon and Lysimachus "gaily enjoyed the spoils of their endeavours" (378; emphasis added).

Novella V.1 is a story of gain and possession, set purposely by Boccaccio in a maritime dimension to bring out more powerfully the oddities and incongruencies of the civilized modern world, where love coincides with a mercantile mentality of possession, where men act like pirates and women are considered mere gain in a sea that defines itself as a space of conquest. As prize and prey, the two women will live for the rest of their lives in the houses of two men in a homeland that is no longer theirs, while the reader is left wondering whether this novella should be in Day IV because of the vivid image of bloodshed and the tragedy consumed in the brides' houses on their wedding day. The two men kill all they meet: "essi, lasciata piena la casa di sangue, di romore e di pianto e di tristizia, senza alcuno impedimento stretti insieme con la loro rapina alla nave pervennero" (V.1.70). The sea, the Eastern Mediterranean, again plays a structural role in IV.3 and shapes itself as the narrative space that mirrors the incongruencies of the changing world, namely the social clash between the crisis of feudalism and the rising capitalism of merchants; it points to the inadequacy and dangers of certain behaviours for the new city that needs to be rebuilt.

In fact, before the six protagonists of the story-Ninetta and her two sisters and Rostagnone and his two young friends- take to the sea from Marseille to Crete, there is quite a lengthy introduction about the social origins of all six and the true motivation for their journey over the Mediterranean. Rostagnone is of noble origin but poor; the two young men (Folco and Ughetto) are very rich and live on their inherited wealth (they do not work). The father of the three young women, each aged 14 to 15 , wished to marry them to their promised husbands upon the father's return from Spain, where he went to deliver some of his merchandise. The father is N'Arnald Civada, who, despite his exceedingly humble origins, had built himself a firm reputation through his work as an honest merchant and amassed a huge fortune, both in money and capital goods, and he now promises his daughters in marriage as if they were just merchandise to deliver and from which he earns his reputation and wealth. Boccaccio offers a dramatic snapshot of what happens with social mobility at work.

The three sisters seem to start their trip from Marseilles to Crete with the three men by choice, but the decision actually derives from Rostagnone's utilitarian calculation of inviting the two young men to his house and delivering a speech that is an open parody of the very core of Ulysses' "orazion picciola" and 
Pampinea's inaugural speech (Intro.64). It is an inspired, manipulative speech based on economic turnout to encourage the two men, completely lovesick for Ninetta's sisters, to embark on a journey "abroad," not to achieve knowledge or virtue, but to establish a new life in a new place by working and earning this life with the women they love. Their only purpose is to choose a place in the world to live a happy life (IV.3.14) in a dishonest way by using a third share of the two men's combined wealth and persuading the three sisters to go as well, bringing with them a substantial part of their father's fortune. This is what Sanguineti defines as Boccaccio's demystification of "la sete umanistico-borghese di conoscenza" by revealing its economic foundation (18) and, I would add, the contradictions brought by social changes. Having chosen Crete as the place to which they should go, the two young men, blinded by excessive love, "vendute alcune possessioni le quali avevano, sotto titolo di volere co' denari andar mercatando, e d' ogni altra or cosa fatti denari, una saettia comperarono e quella segretamente armarono di gran vantaggio" (IV.3.17).In the meantime, Rostagnone convinces Ninetta "with numerous arguments in an effort to win her over to his scheme" (316). The night of their departure, the three sisters open a chest belonging to their father and take a large amount of money and jewellery from it. All six young people hurry aboard the brigantine, which immediately weighs anchor and sets out to sea. The first stop is Genoa and, after eight days of travelling together from harbour to harbour, they arrive in Crete. Here, "assai vicini di Candia fecero bellissimi abituri e dilettevoli; e quivi con molta famiglia, con cani e con uccelli e con cavalli, in conviti e in feste e in gioia con le lor donne i più contenti uomini del mondo a guisa di baroni cominciarono a vivere" (IV.3.19).

What is wrong with this picture and what does this story reveal about the sea as a narrative space that is functional to Boccaccio's poetics in the Decameron? The motivation to leave from Marseilles and cross the Mediterranean was not determined by a hope of "earned" happiness, but by excessive blind love that is soon tainted by blood: basically all of the characters who are far away from home become victims or perpetrators of murder; the only survivor ends up in misery in Rhodes. More than any other novella centred in and around the sea, this novella reveals the sea to be an extension of the city, mobile and hybrid like the social changes occurring inside the city. The sea is structural to the story but also to Boccaccio's poetics as it defines itself as a foreign space of death and mourning for women, almost as a punishment for going beyond the Pillars of Hercules of a female domesticity decided by the women's fathers and brothers. If Bartolomea, 
kidnapped by the pirate Paganino, finds happiness thanks to the sea and freedom from the imposition of her parents, who obliged her to marry the old judge (II.10), the crossing of the Mediterranean here, with its disruptive force, brings out the contradictions of a world dominated by gain and profit, where there is no negotiative space for women who are traded as merchandise.

The illuminations of this novella in both manuscripts (ms. It. 63, fol. 142v; ms. Fr. 239, fol. 120v) show the Mediterranean as a mirror that breaks into a thousand pieces (figs. 15-16). It does not unite but divides. In manuscript It. 63, the illuminator focuses on the departure, when the three sisters are all together on the boat and united by their hands and hugs; in manuscript Fr. 239, the focus of the illuminator is instead on the tragic diaspora of Ninetta and her sisters following the voyage from Marseilles to Crete.

The sea defines itself again in IV.4 as a tragic space of social mobility and contradictions that involves two worlds, feudal and mercantile, as well as two kingdoms, for an Arab princess is in love with a Western man. Like Alatiel, the princess is from North Africa-Tunisia, specifically—and both are promised by their fathers to a king. But she, unlike Alatiel, is in love with Gerbino, the grandson of William II of Sicily, "per sentito dire," according to the Provençal lyric tradition of amor de lonh. The anachronism of the courtly tradition where the Muslim princess is "an object, but a desirable object" (Smarr 137), within a hybrid society that is shaping up between the old and the new emerges more dramatically when the object of desire is Gerbino, more of a pirate-merchant (one of those familiar with the Mediterranean) than a feudal knight of royal birth. He sends jewels to the princess of Tunis "come i mercatanti fanno" (IV.4.8) and speaks like a pirate to his crew, who react accordingly when they are told to assault the Saracen ship bringing the princess from Carthage to her future husband in Granata (IV.4.18-19). The clash of the two worlds occurs when the Saracens show a glove to Gerbino to remind him that he was in breach of the royal pledge that King William, not knowing of Gerbino's love for the princess, had made to the king of Tunis. The pledge allowed the Tunisian to marry his daughter to the king of Granata and ensured that Gerbino and his associate would not interfere with this plan. ${ }^{37}$

The glove, a feudal symbol, soon comes to symbolize a world at the opposite end of the contemporary, dynamic, mercantile world to which his grandson fully belongs, as much as the amor de lonh is completely disconnected from the

${ }^{37}$ At that time, Barbary, that is, Tunisia, happened to be a tributary to the king of Sicily (321). 
culture and the immediacy of an urban world that requires pragmatic awareness. The anachronism of the glove is fully displayed at sea: when it was shown by the Saracen soldiers to Gerbino, the latter retorted that, "quivi non avea falconi al presente perché guanto v' avesse luogo" (IV. 2. 21). However, because of that glove and the breaking of the pledge, the Saracens throw the princess into the sea, which becomes her tomb, and the young man is killed by his grandfather, who cannot withdraw from his promise. The glove and the exemplary punishment with death seem to unfold in a world far away from Boccaccio's in the light of the emergence of the civil, moral, and religious devastations of the plague. Therefore, the hybrid space of the sea becomes the perfect space in which to convey the idiosyncrasies and clashes of social classes, as well as the end of feudalism, to make room for the mobility and liquidity of the modern world. It is no coincidence that it is the Muslims who throw their princess into the sea and not the Sicilians (fig. 17). Here, for Boccaccio, the sea becomes the structural space that conveys, thanks to the novella genre, the problematization of a changing world.

\section{From the domestic into the foreign}

From the sea as a space of disjunction in time and space, a promise of the Mediterranean as a sea of conjunction emerges with the figure of Gostanza from Lipari, Sicily, in Decameron V.2. In this novella, the Mediterranean unites, but that may be because Gostanza is surrounded by other women, as was the case with Iphigenia, who finds respite from her abduction and the troubled sea among Rhodian women. In the illumination in the French manuscript 239, the Tunisian king, who helped Martuccio reunite with Gostanza, is on one side in Tunisia, while the woman stands on the Italian island; they are symbolically united by the boat that bridges the two worlds: Tunisia and Sicily (fig. 18). The Tunisian princess from IV.4 is not as lucky as Alatiel but interestingly shares the same geographic itineraries in the Mediterranean between Sicily and Tunisia as the Sicilian Gostanza; still, why does Boccaccio end the story of the princess so tragically and spare the Sicilian woman and Alatiel? Strong textual connections between these stories become apparent in the illuminations of the manuscripts from the BnF.

Although Gostanza is the only woman in the Decameron who is actually skilled in the art of navigation, she gives herself up to the sea, which allows her to reach a foreign place, Tunisia, and express herself as a woman. Her foreignness/ extraneity is at the centre of the story more than the official theme of the day and 
makes this a true Mediterranean story, an experience of exchange and solidarity between women of different religions and customs. Carapresa recognizes Gostanza as a Christian from her clothes, and Gostanza understands Carapresa as the latter speaks Latin, being an immigrant from Sicily to Tunisia with certain Christian fishermen (fig. 19). ${ }^{38}$ As Gostanza moves, the story also moves into a new, foreign space in the second phase of the tale where language and culture become the dominant themes, since Carapresa shows Gostanza how to integrate herself in Tunisia, by means of learning Arabic and working with other Tunisian women. She brings Gostanza to the house of an old Muslim where only women live, working silk, palm leaves, and different types of leather. The solidarity between her and the other women of a different faith, clture, and language brings her back to the joys of living, allowing her to be productive in the community and to practise the principle of utilitas. How important this notion is for Boccaccio is well known, ${ }^{39}$ but what is the price of integration for Gostanza?

In order to integrate herself, Gostanza has to deny her own culture, language, and faith like Zinevra, who chose to sail dressed as a man and with the new name of Sicurano da Finale from Genoa on a Catalan ship to Alexandria, to run away from the homicidal fury of her husband. We do not learn about Zinevra's journey across the sea, but, through her, we experience her successful integration at the Sultan's court and the multicultural mercantile Acre, where it was the custom to hold a trade-fair within the Sultan's domain, "where merchants both Christian and Saracen, used to congregate in large numbers" (173). ${ }^{40} \mathrm{We}$ are told that she, now called Sicurano, "il quale già ottimamente la lingua sapeva" (II.9.46), would be sent by the Sultan to the trade-fair as a captain in charge of protecting the merchants and their merchandise.

The sea brings Zinevra to a "somewhere else," where she learns Arabic and survives but as a man, denying her identity as a woman and a Christian. She, like

\footnotetext{
${ }^{38}$ Here, Latin stands as a non-Arabic language as in only one other case, Decameron X.9, a story of the Christian Torello and the Arab Saladin.

${ }^{39}$ See Hollander; and Morosini, "Connettività e 'Convivencia'."

40 "Sicurano in poco di tempo non meno e la grazia e l'amor del soldano acquistà col suo bene adoperare, che quella del catalano avesse fatto: per che in processo di poco tempo avvenne che, dovendosi in un certo tempo dell'anno a guisa di una fiera fare una gran ragunanza di mercatanti e cristiani e saracini in Acri (la quale sotto la signoria del soldano era), acciò che i mercatanti e le mercatantie sicure stessero, era il soldano sempre usato di mandarvi, oltre agli altri suoi ufficiali, alcuno de' suoi grandi uomini, con gente che alla guardia attendessse" (II.9.45).
} 
Gostanza, survives in the foreign and religious space, the former by denying her identity and the latter by donning male clothes.

In the cases of Zinevra and Gostanza, the Mediterranean marks the space of its inner hybridity: although they are both integrated in the foreign land and both contribute to the local culture- the first as a captain in charge of the special guard whose duties were to protect merchants and merchandise, and the other to produce useful goods for the community - both cases are problematic because both women, in order to integrate, have to sacrifice their identities. Also, the rubrics of both stories signal that returning home concerns the man, not them. Although they are the centre of our attention while abroad, once they head for home, they become invisible to us. After Gostanza and Martuccio are reunited, we learn that Martuccio "marries her and brings her back with a rich fortune to Lipari" (V.2.1), but there is no word about her except that she found Martuccio alive and well in Tunis and made herself known to him. As for Zinevra, her return home coincides with her regaining female clothes; when the Sultan finds out the truth about her, the first thing he does is provide her with women's clothes of the finest quality and a retinue of ladies (fig. 20). ${ }^{41}$ This conclusion proves that Zinevra would not have survived in a Muslim territory (even working for the Sultan), and through the mercantile exchanges in Acre, if she were not skilled and dressed as a man. ${ }^{42}$ She misses home, ${ }^{43}$ but her return to her homeland is presented as though nothing had ever happened, as we read in the rubric: "ripreso abito femminile, col marito ricchi si tornano a Genova."

\section{The sea, a structural space of the Decameron}

The first questions we asked here were about who travels and if they are changed by their travels.

\footnotetext{
${ }^{41}$ On women disguised as men in medieval Europe, see Hotchkiss. For more on women travelling in male clothes in the Decameron, De mulieribus, and elsewhere in medieval literature, see Morosini, Il mare salato (forthcoming).

${ }^{42}$ On faith, see O'Shea. Zinevra possesses all the qualities of the ideal woman but also "many of the accomplishments to be found in a knight or esquire": she has many skills of men, such as horseback riding, falconry, reading, writing, and bookkeeping, and "she was superior to the average merchant" in all of them.

${ }^{43}$ Zinevra, disguised as Sicurano, "andando da torno veggendo, e molti mercatanti e ciciliani e pisani e genovesi e viniziani e altri italiani vedendovi, con loro volentieri si dimesticava per rimembranza della contrada sua" (II.9.47-48).
} 
David Abulafia rightly notes that the history of the Mediterranean has become an industry lately and, as Fernand Braudel in particular emphasized, there is a tendency to search for the unity of the Mediterranean (Braudel 261), but many tend to forget what the Mediterranean has meant for the peoples who have inhabited its shores and islands or have crossed its surface; "the question then becomes the way human beings directly experienced the sea" (Abulafia, The Great Sea). I attempted to see how men and women experienced the sea, from those who "dipped their toes" in this liquid space to those who, "best of all, took journeys across it, participating directly, in some cases, in cross-cultural trade, in the movement of religious and other ideas" ("Mediterranean History" 221-222), and, like Abulafia, I proposed to note diversity, rather than to search for "unity."

Finally, to measure the changes women experience in their travels, we should examine the motif of return. In the women's journeys, we see missed returns. The transformation or metamorphosis following the nostós, the desire of the hero to return home that is so important for the Homeric hero, is absent. How much has Alatiel changed after her long journey all over the Mediterranean in the Second Day of the Decameron (II.7)? If the word that should accompany movement is "change" (cambiamento), the word that springs to mind with regard to many heroines in transit is "exchange," or, in Italian, s-cambio. When Ulysses crosses the Mediterranean, he measures himself against his destiny. The few women who cross it remind us more of the immobile Penelope. When they return to their domestic world, are they changed by their travels? If not, why? ${ }^{44}$

For women, Boccaccio seems to turn the Mare Nostrum of Homeric memory and nostós, the desire for return, upside-down. In the heroic poems, the hero does not want to be transformed but only to go home; he experiences change passively. Beritola, Alatiel, and Iphigenia all go home when they did not expect to do so and they have changed and learned a new language, even if Boccaccio does not tell us what their lives will be once they are back home.

A place of metanoia, ${ }^{45}$ of transformation, for men, the Mediterranean is a fundamental moment of paideia, but it is not so for women, and not only in the Decameron. In the Filocolo as well, women travel, but the travelling experience does not prompt education and formation. For Florio, who acquires maturity,

\footnotetext{
${ }^{44}$ See Morosini, "Penelopi in viaggio," where I use another illumination to explain the drama of Helen of Troy.

${ }^{45}$ Metanoia is a term already in use in the New Testament (Acts 5:31) and in Joseph Flavius, De Bello Judaico (Book III, section 127), but it is absolutely not intended in religious terms here.
} 
travel is a real initiatic iter, like the aventure of the Arthurian knight whose efforts, according to Matilda Tomaryn Bruckner, are "towards reintegration-reintegration: reintegration of the menaced society itself whose integrity is a guarantee of universal order, and reintegration of the knight within that ideal human organization" (159-160). When Florio organizes Calocepi's civil and social life, he provides for the community's main needs; he gives the people houses, clothes them, and gives them access to education: "a diversi studii delle liberali arti ne dispose alcuni e altri alle meccaniche" (Filoc. V.49.6). When Gostanza joins a new community, her presence has no repercussions. She is welcomed as a woman who can integrate into a society and assimilate its habits and language (V.2). Zinevra can operate on and modify reality only when she wears masculine clothes, while for Ninetta and her sisters the attempt to escape male authority ends in a family tragedy.

The modes of travel for women in the Mediterranean are the same, regardless of social class and religion: rich or poor, Christian or Muslim, crossing those waters for a woman is dangerous and any change is superficial, like every wave that beats Iphigenia. But when women return home, they slip back into their old selves and the word terra/homeland becomes dramatically ironic, notably for Iphigenia and Cassandrea. The man who travels across the Mediterranean is either a merchant ${ }^{46}$ or, like Martuccio (V.2), a poor man who becomes a corsair in order to get rich; or he is like Paganino, a professional corsair from Monaco (II.10), or Gerbino, a nobleman who behaves more as a pirate/merchant (IV.4) and even Cymon (V.1). Despite shipwreck and other misfortunes related to their maritime vicissitudes, most of these men still return home safe and richer than before-except for Giuffredi and the three men from Marseille (IV.3), who cross the Mediterranean for the "wrong" reason, as we discussed. For them, the sea has been a moment of passage to a better life. None of these men visits or discovers an otherness: the Mediterranean with its mobility constitutes the promise of a social mobility (as with the three French men in IV.3), immobility (Giuffredi in II.6), gain (Palermo for Salabaetto in VIII.10), or the crossroad to a land he did not choose to be in (Landolfo II.4, V.2, and Martuccio), but from which he returns happier and better off. The Mediterranean as an agent of the exchange of goods and the main channel of a political and socio-economic network, full of pirates that are hard to distinguish from real merchants, permeates Boccaccio's Mediterranean.

\footnotetext{
46 See Houssaye Michienzi; and on Landolfo Rufolo and his world of trades from and to the Amalfi Coast, see Caskey.
} 
In conclusion, from this study it would appear that Boccaccio does not narrate several Mediterraneans but, rather, one sea in its hybridity that is mirrored through the journeys of men and, in particular, women.

Except for Gostanza, whose luck is that of being welcomed by Carapresa, surrounded by women, and integrated into the Tunisian community to make herself "useful" to the foreign community, the Mediterranean, for the women who cross it, is a sea of dispersion and not a sea of union or convivencia. ${ }^{47}$ Gostanza integrates into the community of Arab women by merging into their culture, learning their language, and giving up her own identity as a Christian from Sicily. Despite the image in manuscript Fr. 239 (fig. 18), where the boat poetically suggests a conjunction between North Africa and Sicily, the sea most definitely does not configure itself as a welcoming place of dialogue and integration.

The sea in the Decameron is the structural mobile space that Boccaccio uses to bring out its deepest conflicts and defines the space of those who cross it: a sea of faith (Alatiel in II.7 and the princess of Tunis in IV.4); of piracy and slavery (Beritola in II.6; Bartolomea in II.10; Restituta in V.6; Teodoro in V.7; and, in VIII.10, the girl-slaves in Palermo); of displacement and reunion for Teodoro, sold as a slave but then reunited with his father on his way back to Armenia; of displacement, disgregation, and disintegration for the three sisters (IV.3); and, rarely a neutralizing space, a place of the resolution of conflicts (Kuortti and Nyman 1).

As for the other question we posed, what difference does a sea make in the Decameron - namely, does the Mediterranean cover a structural role in the text? When I began this study, I thought I might be able to identify these categories in all the novelle featuring the sea that I discussed above, but it has been impossible to do so. Each story featuring the Mediterranean contained two or more of those categories, thus confirming the Mediterranean as a place of hybridity and plurality, rarely a place of conjunction, and definitely not a space of neutralization, since its function, thanks to its ambivalence, is to convey conflicts, including conflicts of gender, religion, and culture, ${ }^{48}$ for this is Boccaccio's privileged narrative space, the most functional to the novella genre.

To be sure, one could try to adopt Corbellari's epistemological categories of interpretation of the sea as a structural space in and of the Decameron to see if

\footnotetext{
47 On the meaning of convivencia, see Cohen; Hames. See also Abulafia ("Mediterranean History"), who identifies in Ramon Llull a representative of the old Iberic concept of convivencia as "recognizing the God of the three Abrahamic religions as the same single God" (226).

${ }^{48}$ See Lewis.
} 
those can be adopted for Boccaccio's text. These categories comprise Conjunction, Disjunction, Neutralization, and Scattering; they are described below:

Conjunction: In the story of Gostanza and Martuccio, as the illumination in manuscript Fr. 239 suggests (fig. 18), the sea makes two different worlds accessible, but we know that Gostanza had to integrate into Arab culture in order to survive. So did Zinevra, and in male clothes.

Disjunction: The sea defines itself more as a space of conflicts than of faith in IV.4 and II.7, as the stories of the Tunisian princess and the Egyptian Alatiel oppose two faiths, two worlds, and, in the case of the princess, also two kingdoms. A conjunction of the two worlds seems to occur in Alatiel's story, but only in Antigono's "fable," and only verbally (through inventio and narration), could Alatiel travel safely across the Mediterranean and be welcomed in a monastery of Christian nuns.

Neutralization: Rarely is the Mediterranean in the Decameron a place of neutralization, a place outside the world where conflicts can be resolved, but in Bartolomea's case (II.10), the displacement brought by the sea neutralizes conflicts, as is wonderfully captured by the artist of the French manuscript Arsenal 5070 (fig. 21). The sea is not a place outside the world; instead, it becomes the representational space of Boccaccio's political vision that he entrusts to this woman. Bartolomea is kidnapped by pirates and when her husband comes to Monaco to bring her back to Pisa, she decides to stay. She is like Restituta on the coast when she is kidnapped, but the sea is an agent of change for Bartolomea, since the displacement from a society where a young woman is given away by her parents to an old man because he is a rich judge brings her an awareness of her civil and political rights and of her own sexuality. ${ }^{49}$ Her husband had imposed on her several "diets" and in her speech filled with verbs and metaphors of production and productivity, her decision to stay with the pirate Paganino becomes a political and social protest where she advocates the right of women to satisfy their erotic desire and be "productive." The Mediterranean indeed becomes the passage from an immobile to "productive space," to use Lefebvre's notion. ${ }^{50}$

Scattering: To this category, of scattering provoked by a storm and a shipwreck that determine the destiny of those who cross the sea, I would add the

\footnotetext{
${ }^{49}$ On the erotico-political, see Morosini, "From the Garden to the Liquid City."

50 "Productive space" is a notion of Lefebvre, in La production de l'espace 370-392. It is a public space as opposed to a private one and is characterized by exchange and productivity.
} 
modern notions of displacement and diaspora; I will clarify with some examples. In the courtly romance, the storm creates a perturbation of the diegesis, but in the Decameron, natural causes do not affect diegesis as much as human intervention does, that is, what men and women decide to do when confronted with a storm or a shipwreck. Storms initially disturb the crossing of the sea, as in the case of Alatiel who is shipwrecked on the island of Mallorca; strong winds push Beritola's ship to Ponza and Iphigenia's ship to Rhodes, while gentle breezes bring Gostanza's ship from Lipari to Tunisia. In these stories, the natural atmospheric element related to the sea contributes to the development of the story, but it is never a structural element of the novella as it is, for example, in the cantare of Bella Camilla. Here, the sea is purely a background for the protagonist, not a "social space," but the space where she can prove her Christian virtues and remain strong and pure. Christian faith makes the sea evangelical. Still, to carry the word of God, Camilla must dress as a man. On the contrary, the sea is a structural element of the stories from the Decameron involving the Mediterranean, always a co-protagonist with human history, namely the pirate raids and the consequent choices of men and women: Alatiel chooses silence because she is aware of her "otherness" and of being in foreign waters; Beritola with her tears withdraws into the "cave"; the princess of Tunis chooses an anachronistic and, therefore, irrational and deadly caprice, that is, amor de lonh, since she is not aware of her own culture. So, it is not "fortune" or natural agents that shape their stories, but the choices that the individuals, those women, make.

The Mediterranean in the Decameron is a cultural space of exclusion and Boccaccio's privileged textual space. Rarely a place of conjunction and unification where conflicts are resolved, it is ultimately the "third space" in Bhabha's terms: its uniqueness in the Decameron is to be a place of hybridity rather than of homogeneity (55). It is a space of dissent, which, thanks to its plurality and hybridity, becomes a structural element of the novella genre, where Boccaccio can narrate the world of merchants and their ports of call, but also the darkest pages of the trade in women and slaves in the medieval Mediterranean.

Boccaccio's invention of modern culture, so intrinsically Mediterranean, unfolds through a narrative space that privileges the sea as a mobile and thus unpredictable space of experience, rather than the forest, a place of shelter and escape from civic responsibilities for the likes of Tristan and Ysolde; this is a space of danger and dehumanization, but, paradoxically, it is also the place where adventures occur that serve to protect the inner space within the castle walls. For 
Boccaccio's brigata, it is the outside that is safe and it is outside the city walls that its members can be changed, as also happens at sea.

A structural element of the novella, the sea takes shape as an extension of Boccaccio's humanistic and civic preoccupation in the Decameron, revealing the essential mobility of the medieval literary text that Paul Zumthor identifies as mouvance (Essai de poétique médiévale), which also permeates the novella, its recording of recurring changes, and the contradictions of the world narrated in the Decameron. From this stems the hybridity of the novella, a genre able to transmit the plurality and the ambiguity of the contemporary world, both familiar and foreign, including the otherness of other races and other spaces. To the sea, its mobility, and its hybridity, Boccaccio entrusts the awareness of his modernity ${ }^{51}$ when, in the Genealogie deorum gentilium, he represents "his study as a ship crossing the sea in a space and in a time that separate him from Ancient culture" (Lummus 101). Boccaccio anchors his boat against the winds and the waves with the awareness of a writer who knows, as pointed out by David Lummus, that he has "founded" (fundavi, serenissime rex) something new, even if upon the instability of the sea. This mobile and hybrid uncertainty of the sea, which best represents the uncertainty of the fourteenth-century world, is the space crossed by Boccaccio the traveller, on his own boat that is his studies, the narrator of the modern world through the sea in the Decameron.

\section{Wake Forest University}

\section{Works Cited}

Abulafia, David. The Great Sea: A Human History of the Mediterranean. London: Penguin; New York: Oxford UP, 2011. . "Mediterranean History as Global History." History and Theory 50.2 (2011): 220-228.

Balestracci, D. Terre ignote, strana gente. Storie di viaggiatori medievali. Bari: Laterza, 2009.

Bauman, Zygmunt. Liquid Modernity. Cambridge: Blackwell, 2000.

${ }^{51}$ I talk more about the sea as the narrative space of modernity in "Giovanni Boccaccio." 
Bhabha, Homi K. The Location of Culture. London and New York: Routledge, 1994.

Boccaccio, Giovanni. Decameron. Ed. Amedeo Quondam, Maurizio Fiorilla, and Giancarlo Alfano. Milan: BUR, 2013.

. The Decameron. Ed. and trans. G. H. McWilliam. 1972. London: Penguin, 2003.

Bolduc, Michelle. "Les reflets du voyage dans le Décaméron: Madame Béritole (II,6) et Alatiel (II,7) et le Vatican MS Palatinus lat. 1989.” In Die Geographie in der Mittelalterlichen Epik = La Géographie dans les textes narratifs médiévaux: Actes du colloque du Centre d'études médievales de l'Université de Picardie Jules Verne, Saint-Valéry-sur-Somme, 28-31 mars 1996. Ed. Danielle Buschinger and Wolfgang Spiewok. Greifswald: Reineke-Verlag, 1996. $15-27$.

Branca, Vittore, ed. Boccaccio visualizzato: Narrare per parole e immagini. 3 vols. Turin: Einaudi, 1999.

Braudel, Fernand. Civiltà e imperi del Mediterraneo nell'età di Filippo II. 1953. Turin: Einaudi, 1986.

Bruckner, Matilda Tomaryn. "Le Chevalier de la Charrette (Lancelot)." In The Romances of Chrétien de Troyes. A Symposium. Ed. Douglas Kelly. Lexington, Kentucky: French Forum Publishers, 1985. 132-181.

Caskey, Jill. Art and Patronage in the Medieval Mediterranean: Merchant Culture in the Region of Amalfi. Cambridge and New York: Cambridge UP, 2004.

Cohen, Mark R. "The 'Convivencia' of Jews and Muslims in the High Middle Ages." 12 May 2009, 16 Oct. 2018. <www.medievalists.net>.

Connochie-Bourgne, Chantal, ed. Mondes marins du Moyen Age. Proceedings from the 30th Conference of the CUERMA, 3-5 Mar. 2005. Senefiance, 52. Aix en Provence: Publications de l'Université de Provence, 2006. 7-10. Corbellari, Alain. "La mer, espace structurant du roman courtois." In Mondes marins du Moyen Agre. Proceedings from the 30th Conference of the CUERMA, 3-5 Mar. 2005. Senefiance, 52. Ed. Chantal Connochie-Bourgne. Aix en Provence: Publications de l'Université de Provence, 2006. 105-113. . "La mer, espace de fragmentation dans le roman courtois: l'exemple du Roman de Silence." Speculum Medii Aevi 3 (1997): 103-111.

Epstein, Steven A. "Hybridity." In A Companion to Mediterranean History. Ed. Peregrine Horden and Sharon Kinoshita. Chichester, West Sussex: Wiley Blackwell, 2014. 345-358. 
. Purity Lost: Transgressing Boundaries in the Eastern Mediterranean, 1000-1400. Baltimore: Johns Hopkins UP, 2006.

Ferrante, J. "Politics, Finance, Feminism in Decameron II 7." Studi sul Boccaccio 21 (1993): 151-174.

Guarracino, Scipione. Mediterraneo. Immagini, storie e teorie da Omero a Braudel. Milan: Bruno Mondadori, 2007.

Hames, Harvey. The Art of Conversion: Christianity and Kabbalah in the Thirteenth Century. Leiden: Brill, 2000.

Hollander, Robert. Boccaccio's Dante and the Shaping Force of Satire. Ann Arbor: U of Michigan P, 1997.

Horden, Peregrine, and Nicholas Purcell. The Corrupting Sea: A Study of Mediterranean History. Oxford: Blackwell, 2000.

Hotchkiss, Valerie R. Clothes Make the Man: Female Cross-Dressing in Medieval Europe. New York: Garland, 1996.

Houssaye Michienzi, Ingrid. Datini, Majorque et le Maghreb (14e-15e siècles). Réseaux, espaces méditerranéens et stratégies marchandes. The Medieval Mediterranean. Leiden: Brill, 2013.

Kinoshita, Sharon, and Jason Jacobs. "Ports of Call: Boccaccio's Alatiel in the Medieval Mediterranean." Journal of Medieval and Early Modern Studies 37.1 (2007): 163-195.

Kuortti, Joel, and Jopi Nyman, eds. Reconstructing Hybridity: Post-Colonial Studies in Transition. Amsterdam: Rodopi, 2007.

Lefebvre, Henri. La production de l'espace. Paris: Anthropos, 1981.

. The Production of Space. Trans. Donald Nicholson-Smith. Oxford: Basil Blackwell, 1991.

Le Goff, Jacques. Il meraviglioso e il quotidiano nell'Occidente medievale. Ed. Francesco Maiello. Trans. Michele Sampaolo. Bari: Laterza, 2007.

Lewis, Bernard. Cultures in Conflict: Christian, Muslims, and Jews in the Age of Discovery. Oxford: Oxford UP, 1995.

Lummus, David. "Boccaccio's Hellenism and the Foundations of Modernity." Medievalia 33 (2012): 101-167.

Marchesi, Simone. Stratigrafie decameroniane. Florence: Olschki, 2004.

Matvejević, Predrag. "Pane zingaro." In Sindbad mediterraneo. Per una topografia della memoria da Oriente a Occidente. Ed. Roberta Morosini and Charmaine Lee. Lecce: Pensa MultiMedia, 2013. 21-24. . Breviario mediterraneo. 1991. Turin: Garzanti, 2008. 
"Mediterraneità." Grande dizionario della lingua italiana. Ed. Salvatore Battaglia. Turin: UTET, 1975.

Morosini, Roberta. "The Merchant and the Siren: Commercial networks and 'Connectivity' in Mediterranean 'space-movement', from Jacopo da Cessole's De ludo scachorum to Decameron VIII 10." Studi sul Boccaccio 46 (2018): 99-135.

. The Tale of Salabaetto and Iancofiore: Decameron VIII.10. In Decameron Day III. Ed. W. Robins. Toronto: U of Toronto P, forthcoming.

- "Restituite dal mare. Approdi e partenze di Santa Restituta: da Cartagine a Ischia, da martire a mercanzia (Decam. V 6; con una nota su V 7 e il Libro del caballero Zifar)." Le tre corone, 6, 2019: 107-123.

. Il mare salato. Spazi, itinerari e attraversamenti del Mediterraneo da Dante a Petrarca e Boccaccio. Rome: Viella, forthcoming.

. "Quell'antica pazzia' di Alessandro e i " passaggi » di Olimpia secondo Boccaccio. Dal De casibus alle Genealogie." Critica del testo XVI.3 (2013): 30-47.

. "Connettività e 'Convivencia' 'negli interstizi' mediterranei." In Sindbad Mediterraneo. Per una topografia della memoria da Oriente a Occidente. Ed. Roberta Morosini and Charmaine Lee. Lecce: Pensa MultiMedia, 2013. 13-18.

"E lavorando semini ciascuno': An Interdisciplinary Reading of Decameron III.4." In Renaissance Studies in Honor of Joseph Connors. Vol. 2. Villa I Tatti 29. Ed. Louis A. Waldman and Machtelt Israëls. Florence: Officina del libro, 2013. 385-393.

. "From the Garden to the Liquid City: Notes on II.10, III.4 and 10, IV.6-7, for a Decameron Poetics of the Erotic-Political Based on Useful Work (civanza)." Heliotropia 12 (2016): 46-89.

. "Fu in Lunigiana'. La Lunigiana e l'epistola di frate Ilario (Codice 8, Pluteo XXIX, Zibaldone Mediceo-Laurenziano) nella geografia letteraria di Boccaccio." The Italianist 29.1 (2009): 50-68.

. "Giovanni Boccaccio." In Il contributo italiano al pensiero europeo. Ed. Giulio Ferroni. Rome: Treccani, 2017. 25-35.

. "The 'In-between Representational Spaces' of Medieval Mediterranean Legends: Arthur, Alexander, Muhammad." In Mapping the Medieval Mediterranean, c. 300-1550: An Encyclopedia of Perspectives in Research. Ed. Amity Law. Leiden: Brill, forthcoming. 
. "Introduction." In Boccaccio veneto: Settecento anni di incroci mediterranei a Venezia. Proceedings of the International Conference, 20-22 June 2013, Wake Forest University, Casa Artom, Venice. Ed. Luciano Formisano and Roberta Morosini. Ariccia: Aracne, 2015. 9-13.

. "Penelopi in viaggio 'fuori rotta' nel Decameron e altrove. 'Metamorfosi' e scambi nel Mediterraneo medievale." California Italian Studies 1.1 (2010): 1-32.

. Boccaccio geografo. Florence: Polistampa, 2010.

- "Per difetto rintegrare»: Una lettura del Filocolo di G. Boccaccio. Ravenna: Longo, 2004.

Neuschäfer, Hans-Jörg. “Boccace et l'origine de la nouvelle." In La Nouvelle : formation, codification et rayonnement d'un genre médiéval: actes du colloque international de Montréal, McGill University, 14-16 octobre 1982. Ed. Michelangelo Picone, Giuseppe Di Stefano, and Pamela D. Stewart. Montreal: Plato Academic Press, 1983. 103-110.

O'Shea, Stephen. Sea of Faith: Islam and Christianity in the Medieval Mediterranean World. New York: Walker and Company, 2006.

Osgood, C. Boccaccio on Poetry. Princeton: Princeton UP, 1930. New York: The Liberal Arts Press, 1956.

Pastré, J. M. "Traversée maritimes et géographie du mythe dans les romans de Tristan." In Mondes marins du Moyen Âge. Proceedings from the 30th Conference of the CUERMA, 3-5 Mar. 2005. Senefiance, 52. Ed. Chantal Connochie-Bourgne. Aix en Provence: Publications de l'Université de Provence, 2006. 367-376.

Picone, Michelangelo. Boccaccio e la codificazione della novella. Letture del Decameron. Ravenna: Longo, 2008. . Il racconto. Bologna: Il Mulino, 1985.

. Il racconto nel Medioevo. Francia, Provenza, Spagna. Bologna: Il Mulino, 2012.

Picone, Michelangelo, Giuseppe Di Stefano, and Pamela D. Stewart, eds. La Nouvelle : formation, codification et rayonnement d'un genre médiéval : actes $d u$ colloque international de Montréal, McGill University, 14-16 octobre 1982. Montreal: Plato Academic Press, 1983.

Ruel, Anne. "L'invention de la Méditerranée." Vingtième siècle. Revue d'histoire 32 (1991): 7-14.

Sanguineti, Federico. "Quarta giornata." Heliotropia 4.1-2 (2007): 1-19. 
What a Difference a Sea Makes in the Decameron:

The Mediterranean, a Structural Space of the Novella

Smarr, Janet Levarie. "Altre razze ed altri spazi nel Decameron." In Boccaccio geografo. Un viaggio nel Mediterraneo tra le città, i giardini e... il 'mondo' di Giovanni Boccaccio. Ed. Roberta Morosini. Florence: Mauro Pagliai, 2010. 133-158.

Zumthor, Paul. Essai de poétique médiévale. Paris: Seuil, 1972. . La misura del mondo. La rappresentazione dello spazio nel Medio Evo. Trans. Simonetta Varvaro. Bologna: Il Mulino, 1995. 


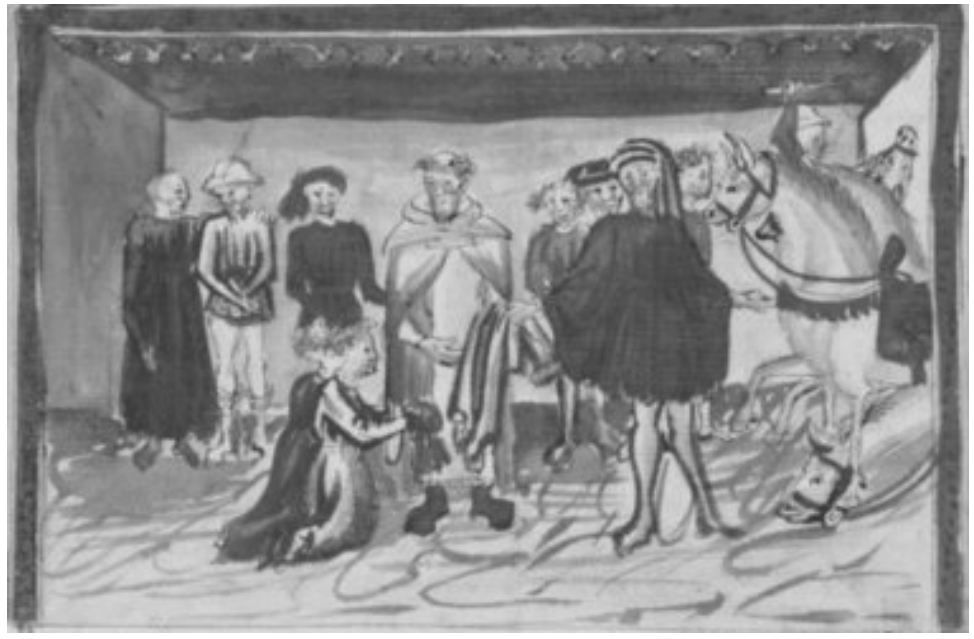

Fig. 1. The lady of Guascony in a world of men: assaulted on her pilgrimage to the Holy Sepluchre asks the king of Cyprus for justice, Boccaccio, Decameron I.9, ms. It. 63, fol. 29v., Florence 1427, BnF, Paris.

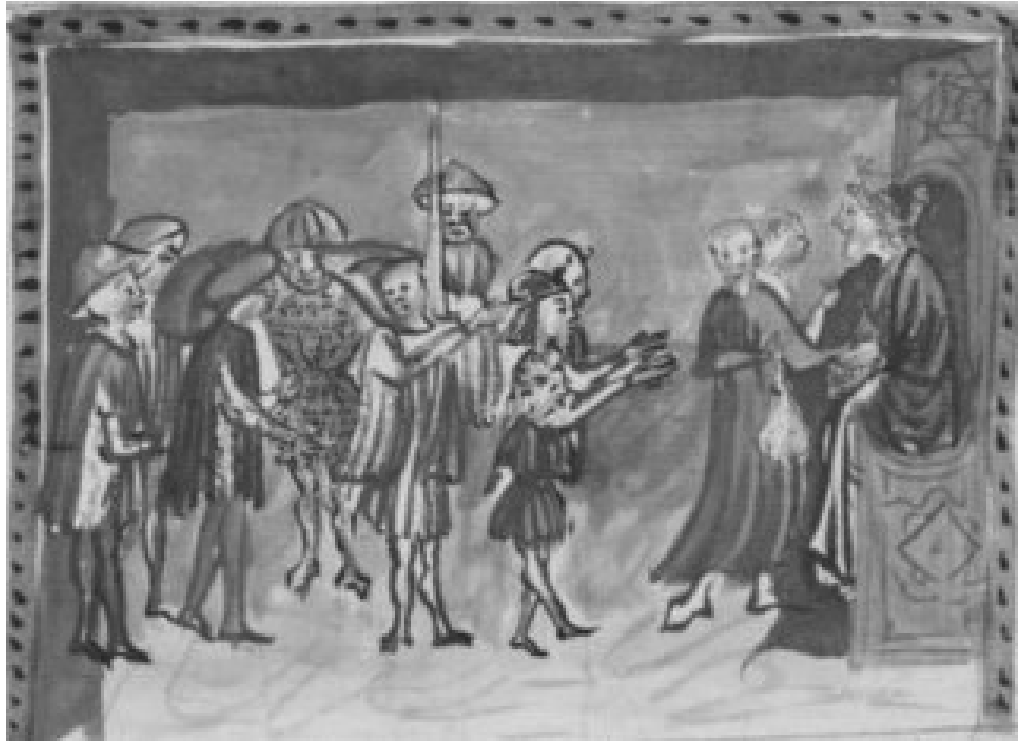

Fig. 2. The three brigands who assaulted Rinaldo d'Asti are executed, in Boccaccio, Decameron II.2, ms. It.63, fol. 36v, Florence 1427, BnF, Paris. 
What a Difference a Sea Makes in the Decameron:

The Mediterranean, a Structural Space of the Novella

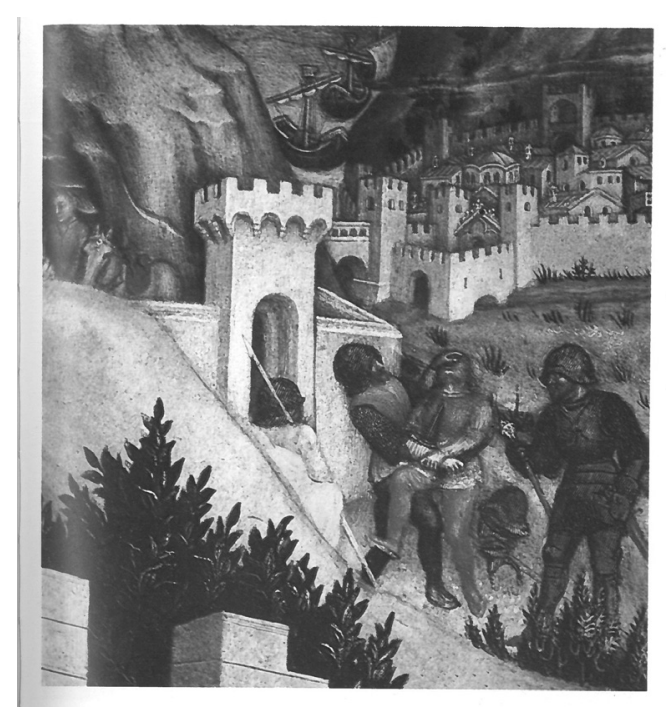

Fig. 3. Gentile da Fabriano, Detail from Adoration of the Magi, 1423, Florence, Museo degli Uffizi.

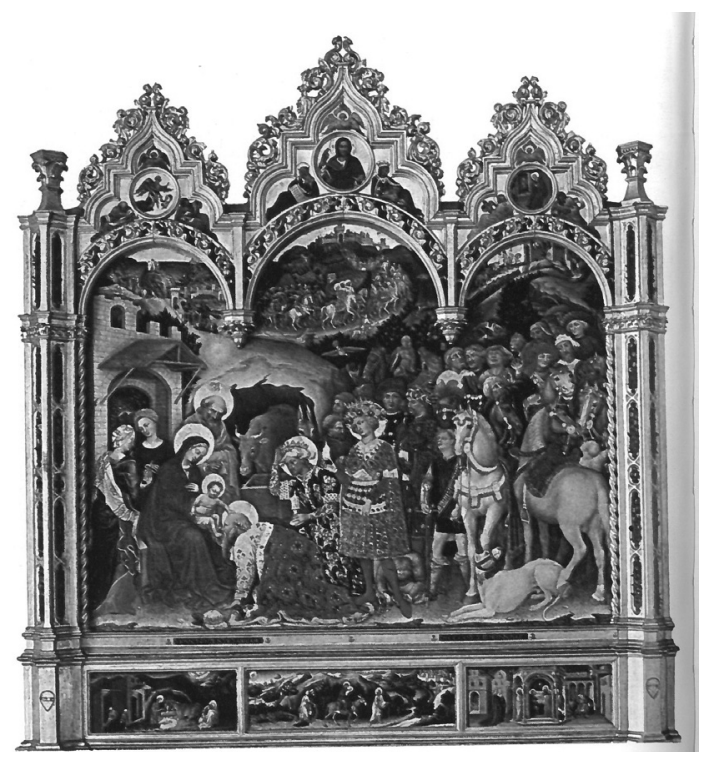

Fig. 4. Gentile da Fabriano, Adoration of the Magi, 1423, Florence, Museo degli Uffizi. 


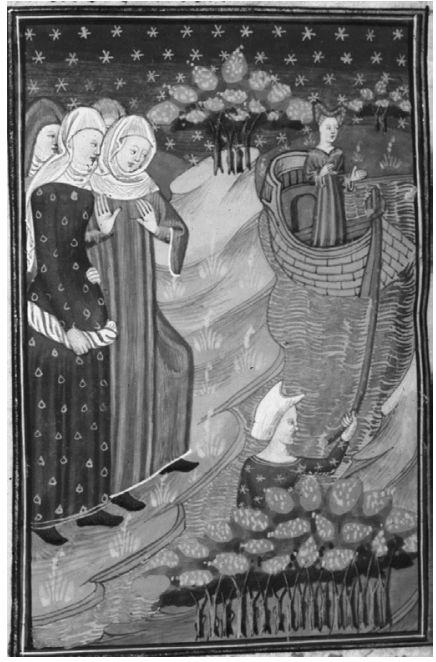

Fig. 5. Claudia Quinta freeing the ship of Cybele with her girdle, in De claris mulieribus, ms Royal 16 G V., fol. 90v, Rouen, France, 1440ca., London, British Library.

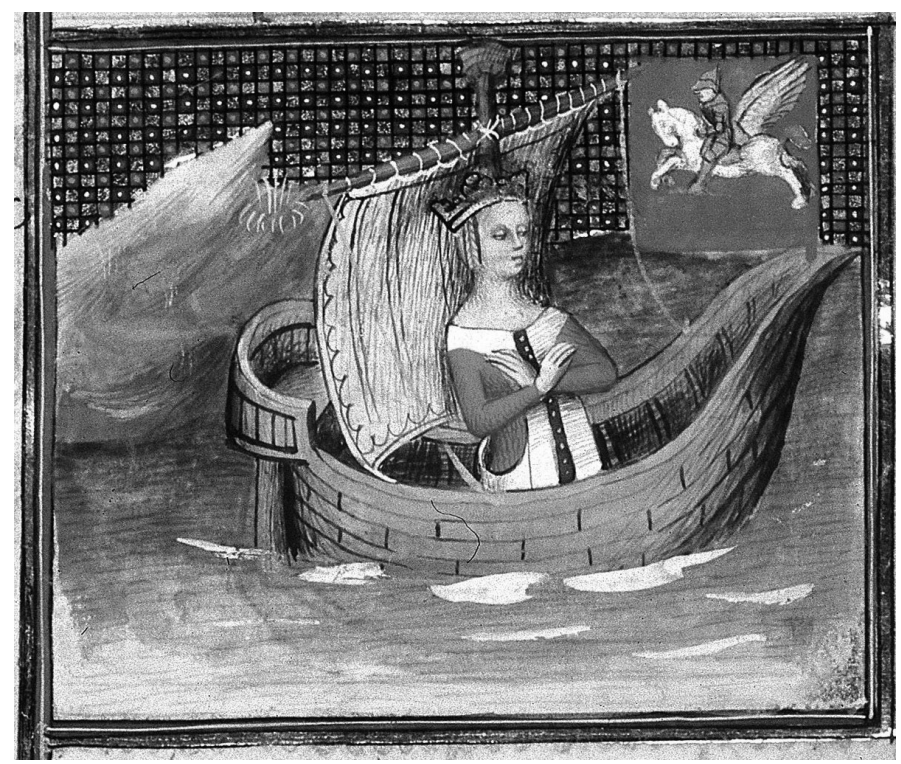

Fig. 6. Medusa on a ship, Boccaccio, De claris mulieribus, ms. Royal 16 G V, fol. 23v, Rouen, Francia, 1440 ca., London, British Library. 
What a Difference a Sea Makes in the Decameron:

The Mediterranean, a Structural Space of the Novella

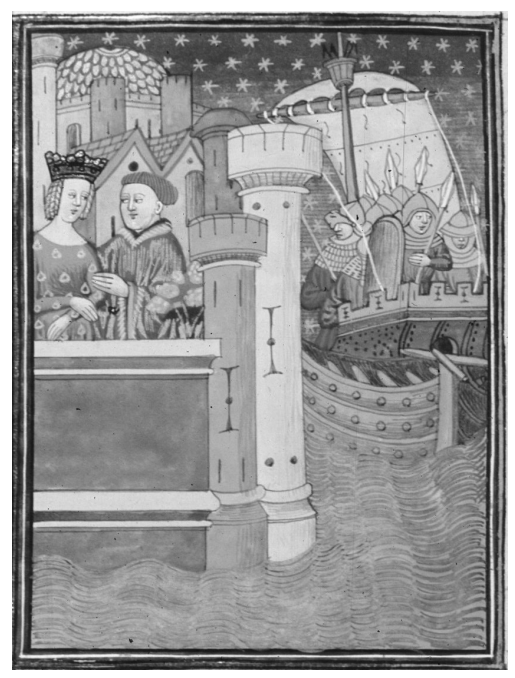

Fig. 7. Helene and Paris, Boccaccio, De mulieribus, ms. Royal 20 C V, fol. 54, I quarto del XV sec., British Library.

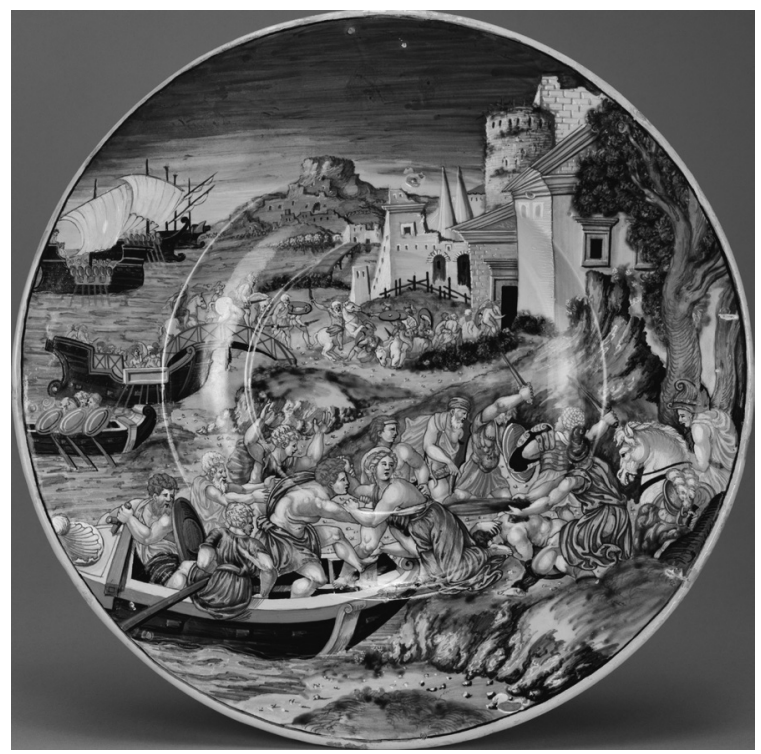

Fig. 8. Francesco Xanto Avelli (Italian, 1486/1487-about 1544). Plate with the Abduction of Helen, 1534, Tin-glazed earthenware. $6.4 \times 46 \mathrm{~cm}(21 / 2 \times 181 / 8$ in.), 84.DE.118. The J. Paul Getty Museum, Los Angeles. 


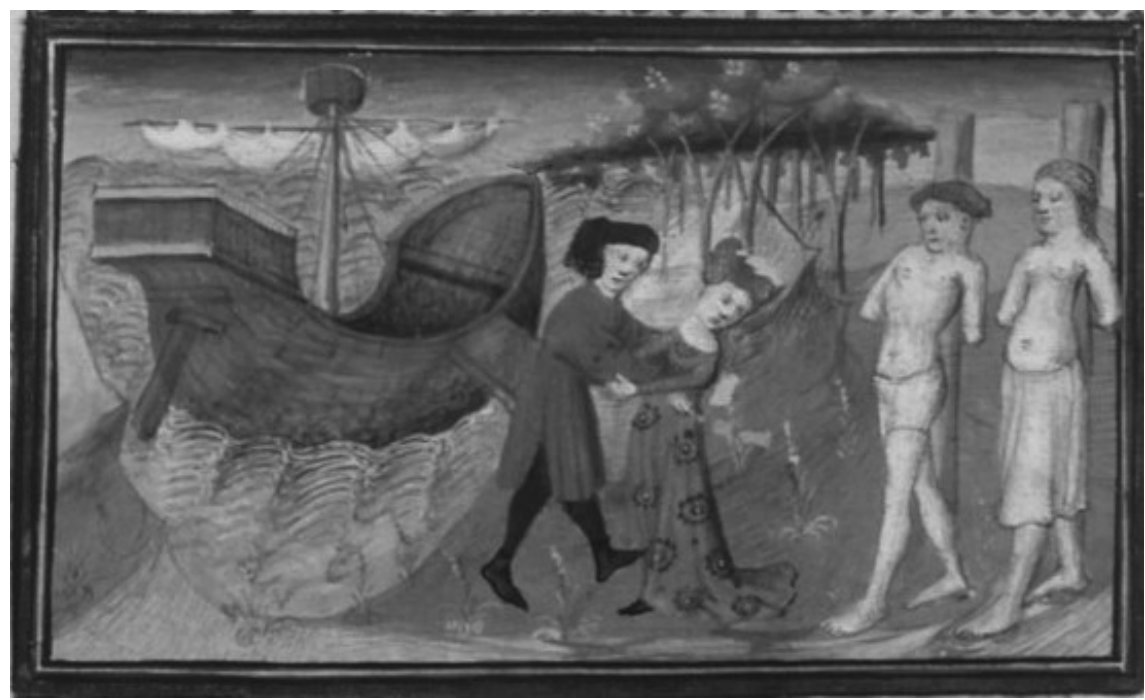

Fig. 9. Abduction of Restituta, in Decameron (trans. Laurent de Premierfait), ms. Fr. 239, fol. $154 \mathrm{v}$, II quarter of 15 th Century.

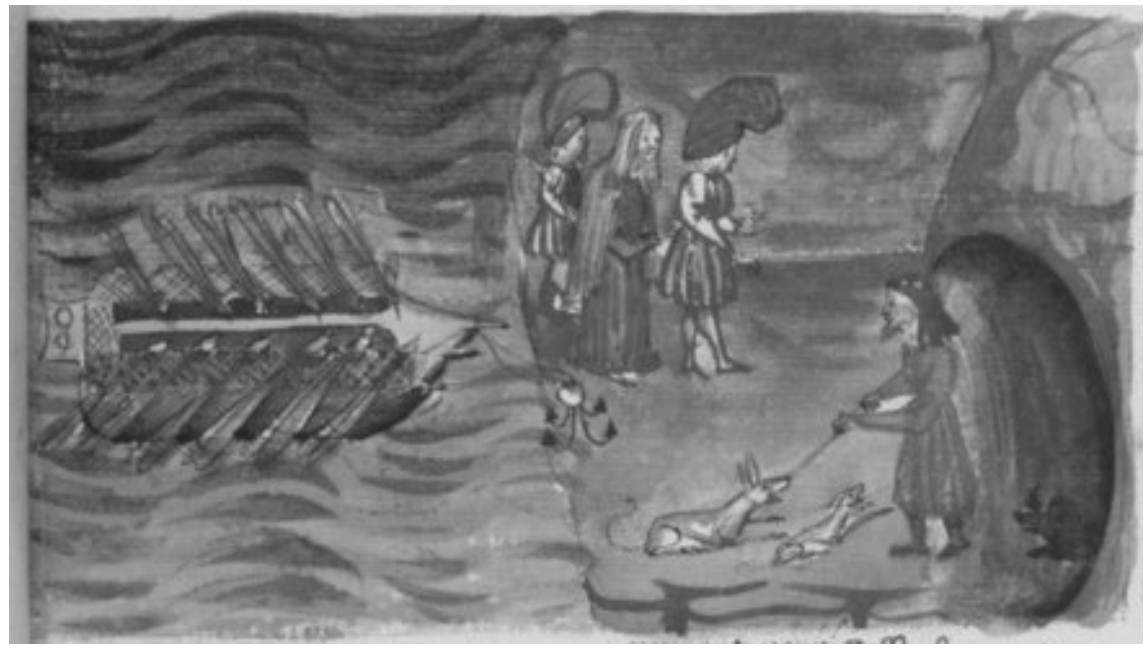

Fig. 10. Corrado Malaspina and his wife in Ponza returning from a pilgrimage. Beritola and "her" cave, in Boccaccio, Decameron II 6, ms. It. 63, fol.53, Florence 1427, BnF, Paris. 
What a Difference a Sea Makes in the Decameron:

The Mediterranean, a Structural Space of the Novella

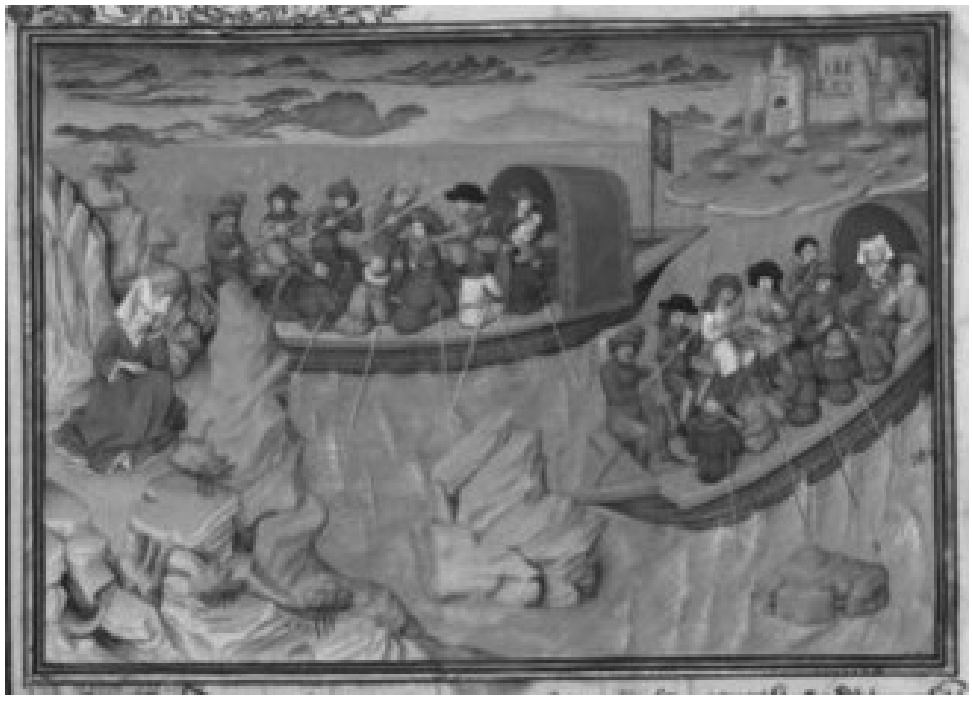

Fig. 11. The nurse and Beritola's sons kidnapped by the pirates, in Boccaccio, Decameron II.6, ms. Arsenal 5070, fol. 60v, artist maitre du Mansel, France II quarter of 15 th Century, BnF, Paris.

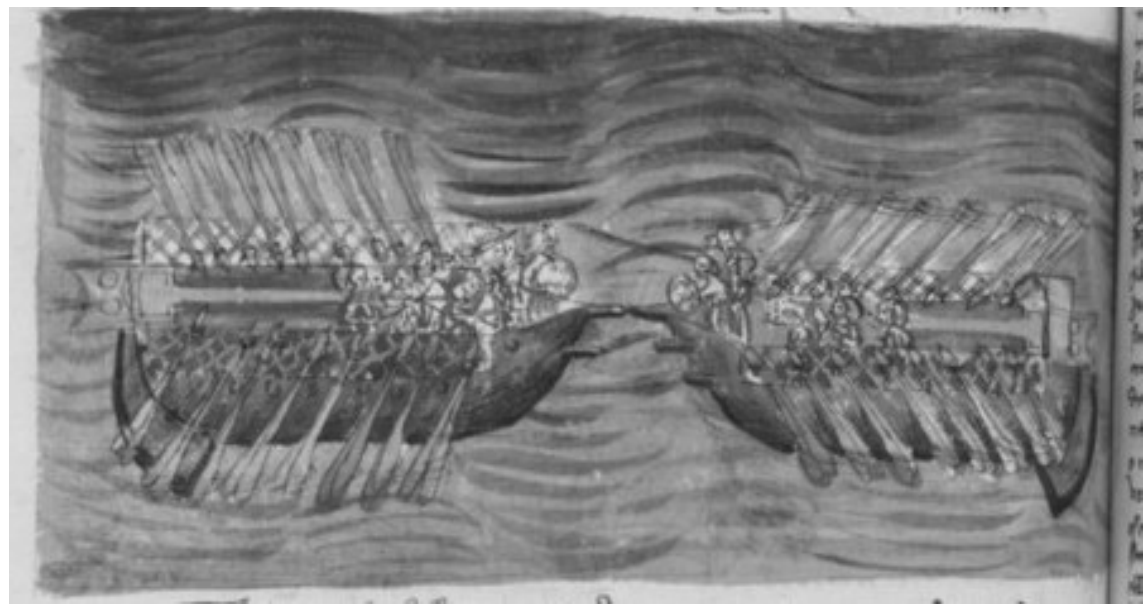

Fig. 12. Alatiel in the Mediterranean, in Boccaccio, Decameron II. 7, ms. It. 63, fol.59v, Florence 1427, BnF, Paris. 


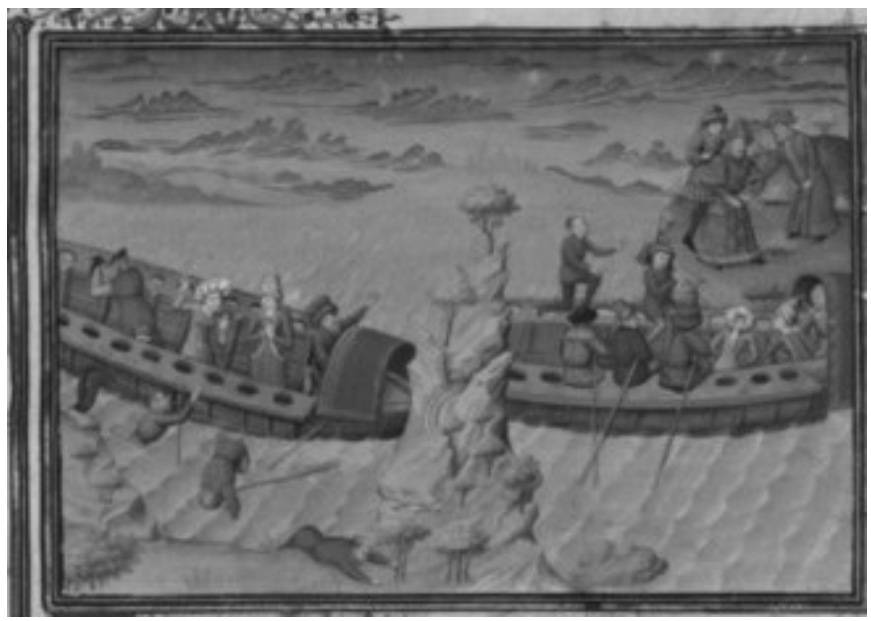

Fig. 12bis. The men on the boat abandon Alatiel and the ship in the storm, in Boccaccio, Decameron II.7, in ms. Arsenal 5070, fol. 67, France II quarter of 15th Century, BnF, Paris.

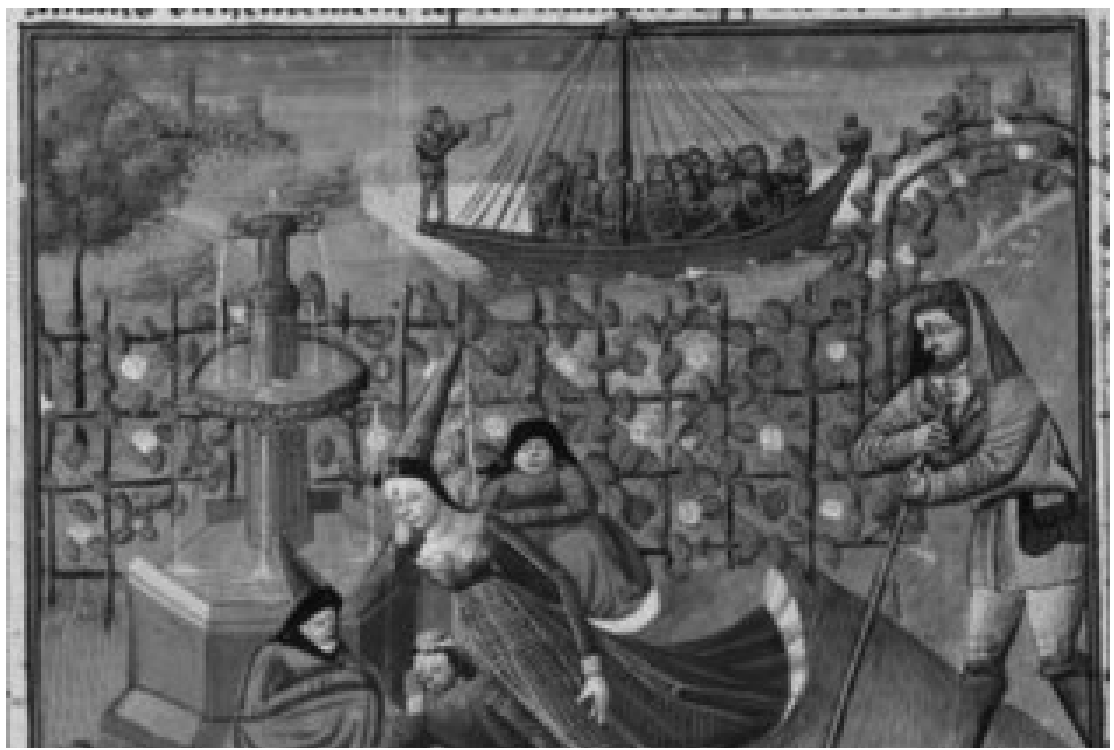

Fig. 13. Cimone admiring Efigenia and the threatening sea, ms. Fr. 240, fol 137v, France III quarter of 15 th Century, BnF, Paris. 
What a Difference a Sea Makes in the Decameron:

The Mediterranean, a Structural Space of the Novella

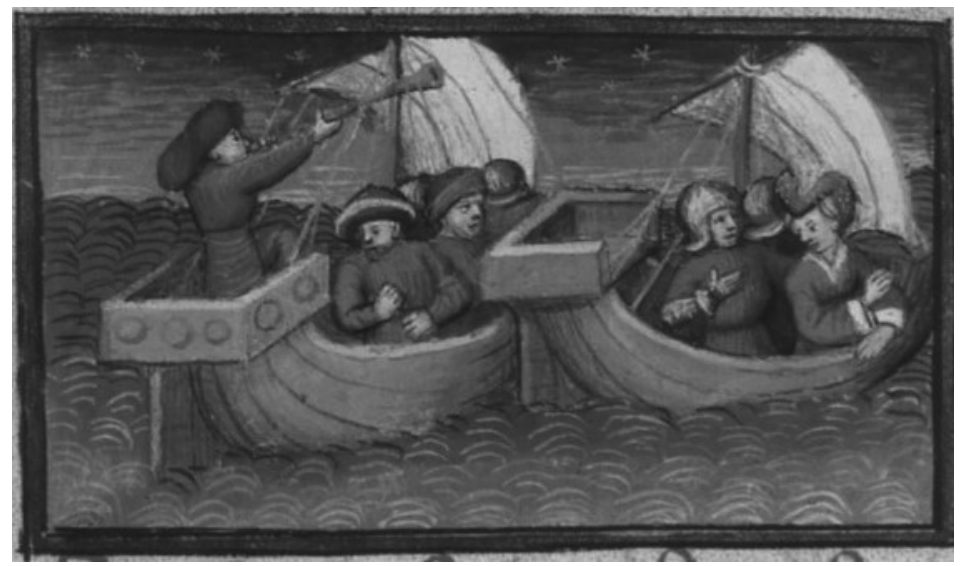

Fig. 14. Abduction of Efigenia at the sea, in Decameron V.1 (trans. Laurent de Premierfait), ms. Fr, 239, fol. 141, II quarter of 15th Century, BnF, Paris.

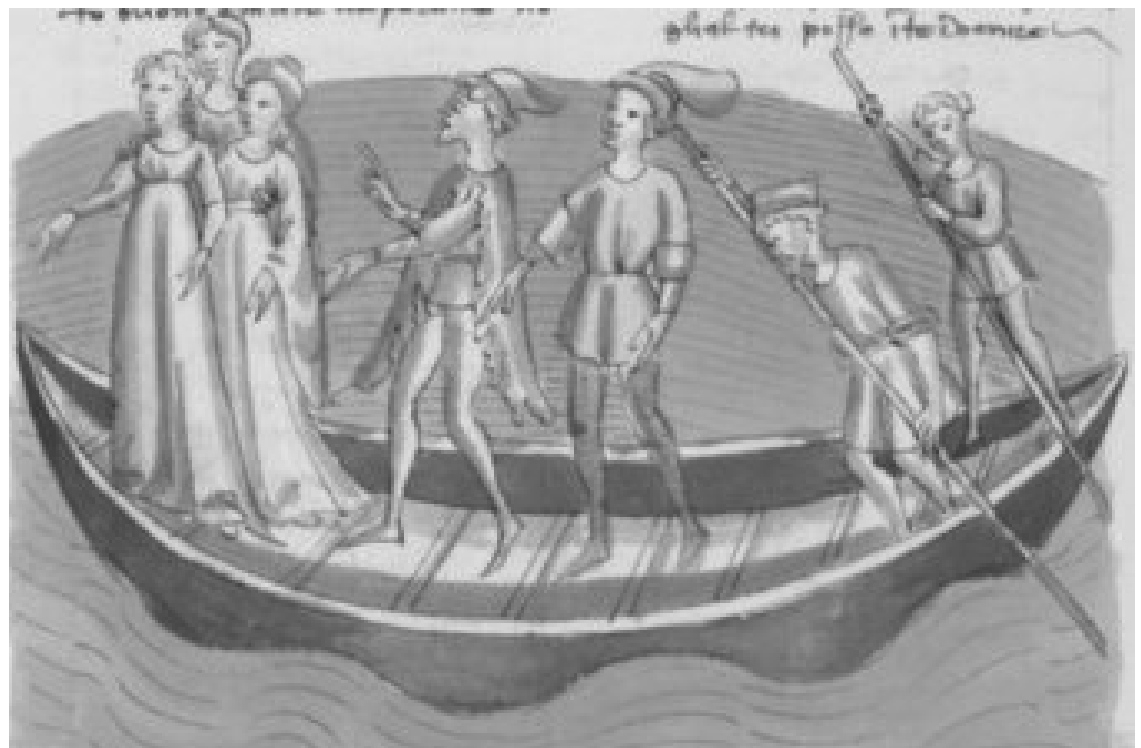

Fig. 15. The three sisters leaving Marseille, in Boccaccio, Decameron IV.3, ms. It. 63 fol. 142 v, Florence 1427, BnF, Paris. 


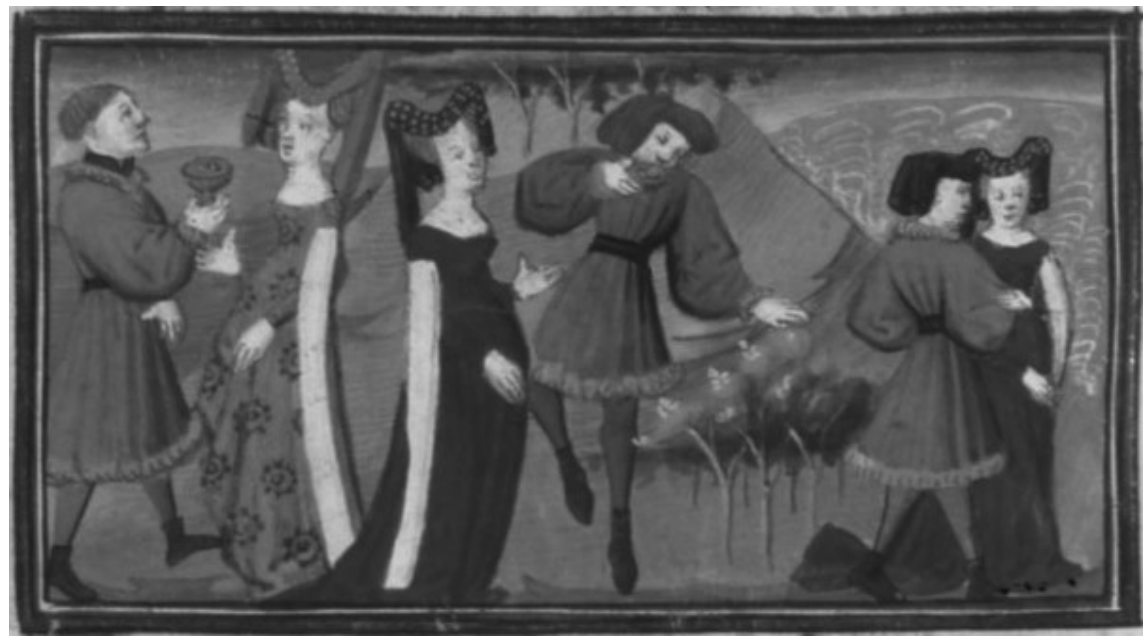

Fig. 16. Death and separations of the three sisters: Nina poisons Rostignone. Madeleine and the duke of Crete, ms. Fr. 239, fol. 120v, II quarter of 15th Century, BnF, Paris.

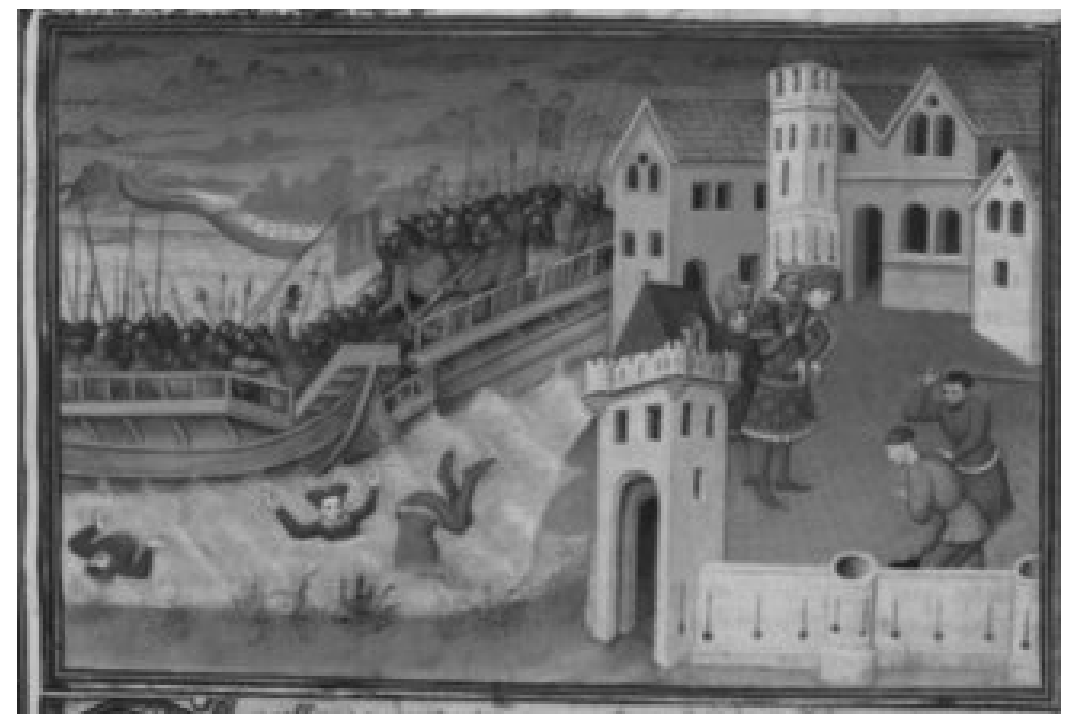

Fig. 17. The Saracens show the glove to Gerbino. The princess of Tunis dies in the sea and Gerbino is behaded, in Boccaccio, Decameron IV. 4, ms. Arsenal 5070, fol. 159, artist maître de Guillbert de Metz, France, II quarter of 15th Century, BnF, Paris. 
What a Difference a Sea Makes in the Decameron:

The Mediterranean, a Structural Space of the Novella

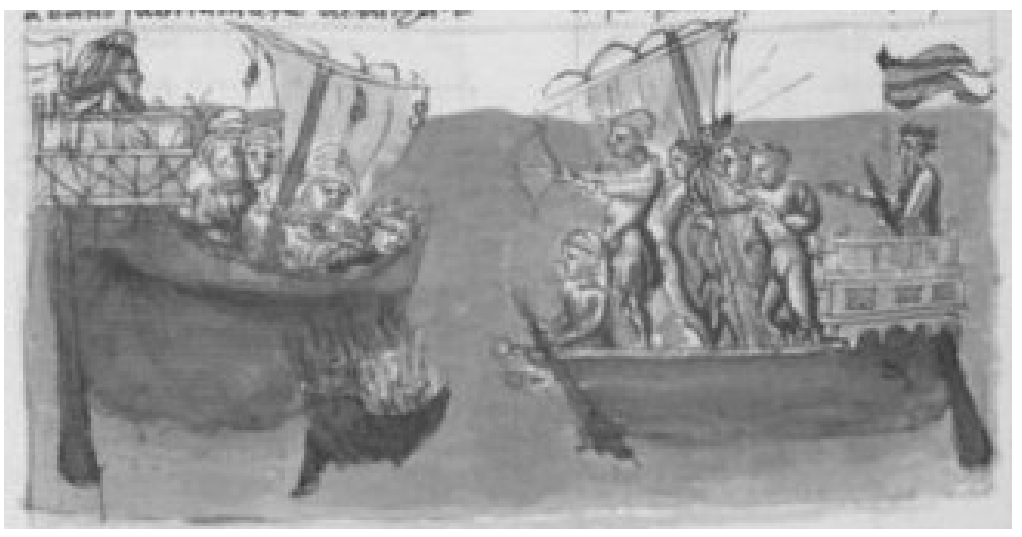

Fig. 18. The Tunisians kill the Princess in the Mediterranean, in Boccaccio, Decameron, IV.4, Paris, BnF, ms. It. 63, fol. 145v., France II quarter of 15th Century, BnF, Paris.

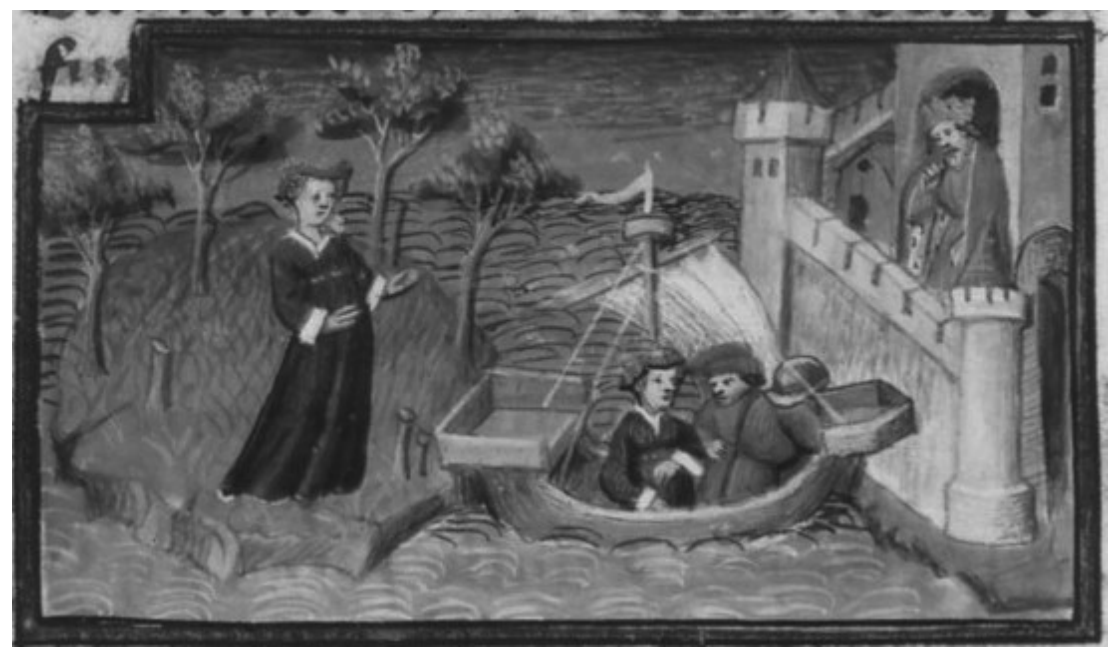

Fig. 19. Costanza between Sicily and Tunis, in Boccaccio, Decameron V.2, ms. Fr. 239, fol. 145v, France II quarter of 15th Century, BnF, Paris. 


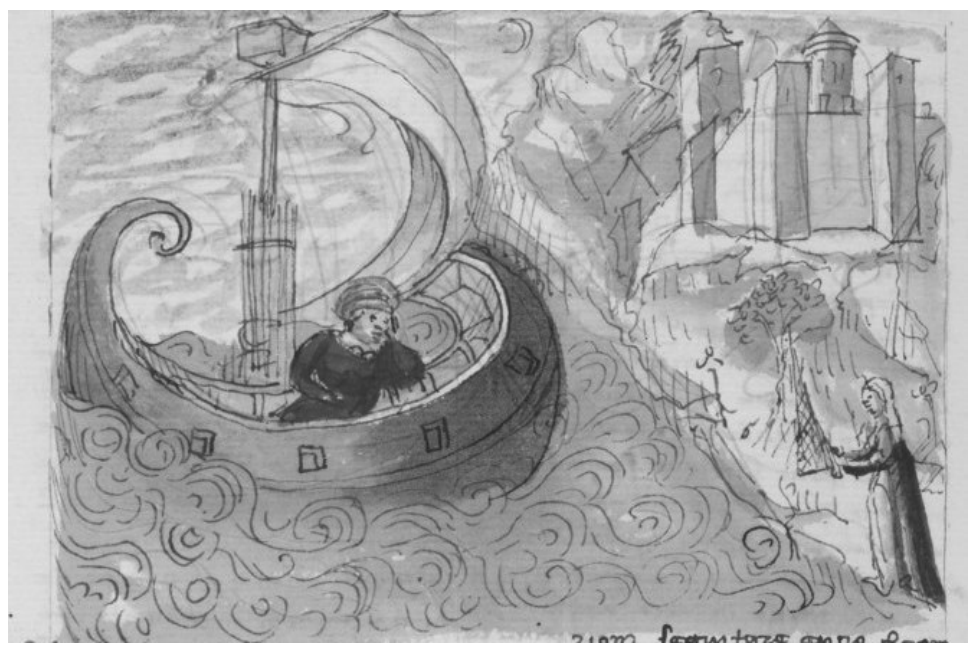

Fig. 20. Carapresa on the Tunisian shore rescues Costanza, in Boccaccio Decameron V.2, ms. It. 63, fol.169v, Florence 1427, BnF, Paris.

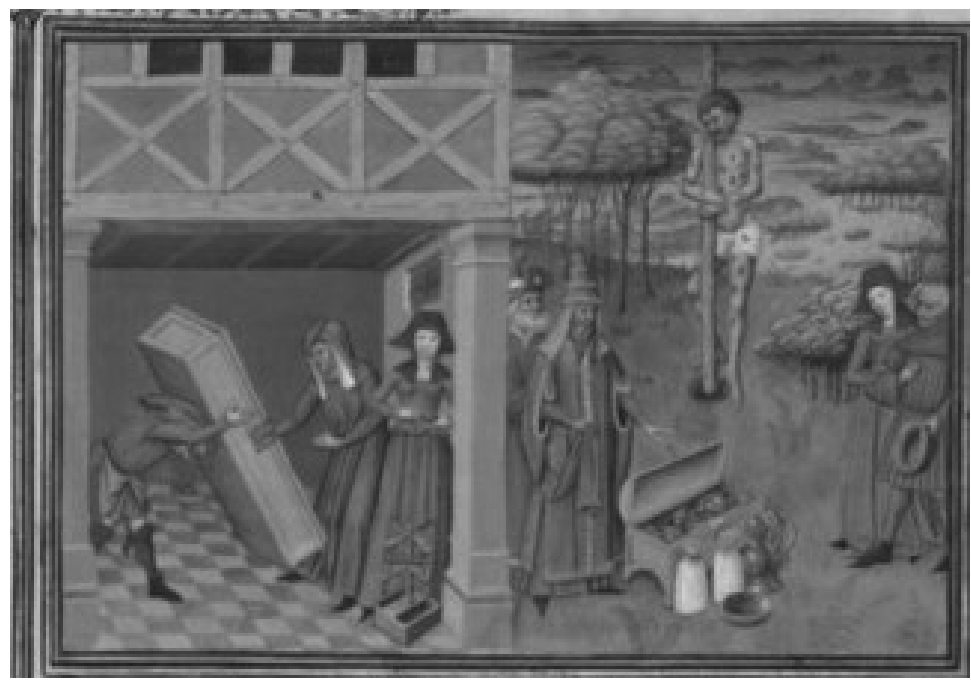

Fig. 21. Zinevra in female clothes and her husband rewarded by the Soldan, in Boccaccio, Decameron II.9, ms. Arsenal 5070, fol.89r, artist maitre de Guillebert de Metz et collab,, II quarter of 15 th Century, BnF, Paris. 
What a Difference a Sea Makes in the Decameron:

The Mediterranean, a Structural Space of the Novella

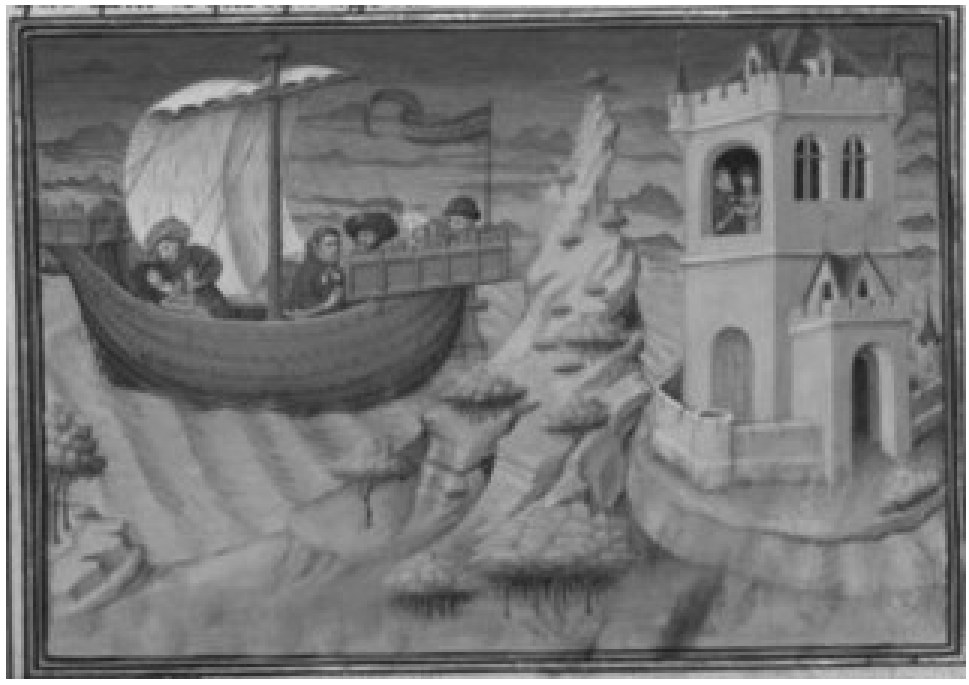

Fig. 22. Bartolomea and Paganino on the boat of the pirates, in Boccaccio, Decameron II.10, ms. Fr. Arsenal 5070, fol.91v, artist maitre de Guillebert de Metz et collab., France, II quarter of XV Century, BnF, Paris. 